\title{
35 yr of stratospheric aerosol measurements at Garmisch-Partenkirchen: from Fuego to Eyjafjallajökull, and beyond
}

\author{
T. Trickl, H. Giehl, H. Jäger, and H. Vogelmann \\ 82467 Garmisch-Partenkirchen, Germany \\ Correspondence to: T. Trickl (thomas.trickl@kit.edu) \\ Received: 23 July 2012 - Published in Atmos. Chem. Phys. Discuss.: 6 September 2012 \\ Revised: 16 April 2013 - Accepted: 23 April 2013 - Published: 24 May 2013
}

Karlsruher Institut für Technologie, Institut für Meteorologie und Klimaforschung (IMK-IFU), Kreuzeckbahnstr. 19,

\begin{abstract}
Lidar measurements at Garmisch-Partenkirchen (Germany) have almost continually delivered backscatter coefficients of stratospheric aerosol since 1976. The time series is dominated by signals from the particles injected into or formed in the stratosphere due to major volcanic eruptions, in particular those of El Chichon (Mexico, 1982) and Mt Pinatubo (Philippines, 1991). Here, we focus more on the long-lasting background period since the late 1990s and 2006 , in view of processes maintaining a residual lowerstratospheric aerosol layer in absence of major eruptions, as well as the period of moderate volcanic impact afterwards. During the long background period the stratospheric backscatter coefficients reached a level even below that observed in the late 1970s. This suggests that the predicted potential influence of the strongly growing air traffic on the stratospheric aerosol loading is very low. Some correlation may be found with single strong forest-fire events, but the average influence of biomass burning seems to be quite limited. No positive trend in background aerosol can be resolved over a period as long as that observed by lidar at Mauna Loa. We conclude that the increase of our integrated backscatter coefficients starting in 2008 is mostly due to volcanic eruptions with explosivity index 4, penetrating strongly into the stratosphere. Most of them occurred in the mid-latitudes. A key observation for judging the role of eruptions just reaching the tropopause region was that of the plume from the Icelandic volcano Eyjafjallajökull above Garmisch-Partenkirchen (April 2010) due to the proximity of that source. The top altitude of the ash above the volcano was reported just as $9.3 \mathrm{~km}$, but the lidar measurements revealed
\end{abstract}

enhanced stratospheric aerosol up to $14.3 \mathrm{~km}$. Our analysis suggests for two or three of the four measurement days the presence of a stratospheric contribution from Iceland related to quasi-horizontal transport, differing from the strong descent of the layers entering Central Europe at low altitudes. The backscatter coefficients within the first $2 \mathrm{~km}$ above the tropopause exceed the stratospheric background by a factor of four to five. In addition, Asian and Saharan dust layers were identified in the free troposphere, Asian dust most likely even in the stratosphere.

\section{Introduction}

The stratospheric aerosol layer continues attracting research activities because of its impact on radiation (e.g., Charlson et al., 1991; Hansen et al., 1997; Robock, 2000; Solomon et al., 2011) and air chemistry, in particular ozone depletion (e.g., Pittock, 1965; Grams and Fiocco, 1967; Jäger and Wege, 1990; Solomon et al., 1996; Solomon, 1999). Research is needed to elucidate further the different sources, in particular those for which a positive trend is expected. Bigg (1956) concluded a potential tropospheric source of the stratospheric particles from meteorological correlations, which questioned a cosmic origin also discussed at that time. The detection of the mainly sulphuric nature of stratospheric aerosol (Junge and Manson, 1961; see also Berresheim and Jaeschke, 1983) then gave a strong hint at its principal relation to strong volcanic eruptions via particle formation from the emitted $\mathrm{SO}_{2}$ gas. With the advent of laser sounding this layer could be 
sensitively detected (Fiocco and Grams, 1964). Since 1972, time series have been obtainable from lidar measurements, balloon ascents (Hofmann et al., 1975), and also satellite observations (McCormick et al., 1981; Thomason et al., 1987). For recent reviews see Deshler et al. (2006) and Deshler (2008). These observations, covering a number of important eruptions, have led to clear evidence of the mainly volcanic nature of the stratospheric aerosol. Long-lasting aerosol signatures are only expected for a significant penetration of a volcanic plume into the stratosphere (Deshler, 2008). Secondary sources could be strong injections from biomass burning (e.g., Fromm and Servranckx, 2003; Fromm et al., 2000, 2008a, b, 2010), likely to become more important in a warmer climate, or emissions by air traffic. Also, a potential influence of the growing Asian $\mathrm{SO}_{2}$ emissions from coal burning has been discussed (Hofmann et al., 2009).

In 1973, a backscatter lidar was installed in GarmischPartenkirchen (Germany), sufficiently powerful for aerosol measurements to more than $30 \mathrm{~km}$. This system yielded routine measurements of tropospheric backscatter profiles over a long period of time (Reiter and Carnuth, 1975; W. Carnuth, unpublished results). After adding single-photon counting to the analogue detection in 1976 the measurements were extended into the stratosphere. The stratospheric series has been carried on until now with short interruptions mainly caused by technical problems. A scientific summary for the period 1976-1999 was given by Jäger (2005). Deshler et al. (2006) and Deshler (2008) compared the results with those from the most important stations performing stratospheric aerosol sounding.

In 1991 the system was integrated into the Network for the Detection of Stratospheric Change (NDSC; now: NDACC, Network for the Detection of Atmospheric Composition Change). Since 1998 the lidar has also contributed to the German Lidar Network (Bösenberg et al., 2001) and later the European Aerosol Research Lidar Network (EARLINET; Bösenberg et al., 2003).

During the past, the volcanic signatures observed with the lidar have been caused by eruptions in parts of the world rather distant from our site. A new situation arose with the eruption of the Icelandic volcano Eyjafjallajökull in April 2010, a source substantially closer to the observational sites in Central Europe. The advection to Garmisch-Partenkirchen was direct due to an anti-cyclonic flow pattern, and additional stratospheric aerosol was observed. The top altitude of the ash cloud reached over the volcano is reported to range between 8.5 and $9.3 \mathrm{~km}$ (Arason et al., 2011) during the first phase. Given the low tropopause in Arctic spring, it has been reasonable to assume some stratospheric contribution, which could explain our observation. In addition, some hot gas carrying finer particles or leading to the formation of aerosol could have ascended beyond the reported ash plume and reached the lower stratosphere.

This eruption was important also because of the proximity to EARLINET, Garmisch-Partenkirchen being a rural station of that network pretty much in its centre. After the first warning around noon on 15 April 2010, co-ordinated measurements have been performed during the two eruption periods in April and May 2010 that reached rather different parts of Europe, demonstrating the importance of such a lidar network, in particular in view of the shutdown of European air traffic over many days. In addition, extensive aircraft-based measurements have been made (Schumann et al., 2011). The observations have led to studies of the spatial propagation of the plume (Ansmann et al., 2010; Flentje et al., 2010; Schumann et al., 2011; Dacre et al., 2011; Emeis et al., 2011; Gasteiger et al., 2011; Mona et al., 2012; Pappalardo et al., 2013; Rauthe-Schöch et al., 2012), microphysical properties (Ansmann et al., 2010, 2011; Gasteiger et al., 2011; Seifert et al., 2011; Groß et al., 2012; Mona et al., 2012) and ice formation (Hoyle et al., 2011; Seifert et al., 2011; Steinke et al., 2011; Bingener et al., 2012). Estimates of the aerosol mass have been attempted (Ansmann et al., 2011; Gasteiger et al., 2011). The conversion of optical coefficients into mass can be made with a relative uncertainty of less than $20 \%$ with the exception of fresh volcanic plumes containing particles with radii of more than $15 \mu \mathrm{m}$ (Ansmann et al., 2011). This approach can, therefore, be used for decisions on air traffic.

In this paper, we give a brief overview of previous findings during the $35 \mathrm{yr}$ of measurements at GarmischPartenkirchen. However, the focus here is on the long stratospheric background period after 1997 and the processes determining the residual stratospheric aerosol under these conditions. The volcanic phase following this background period is used for examining the impact of moderate eruptions. Due to its proximity to our site the Eyjafjallajökull eruption in April 2010, which just reached the tropopause region, was expected to yield relevant information on the potential stratospheric impact of an event of that magnitude. A detailed presentation of our results for the Eyjafjallajökull eruption is given in Sect. 4. Section 4 also includes the tropospheric part of our measurements, Garmisch-Partenkirchen being the southernmost EARLINET station reached by the plume during its direct first approach.

\section{Lidar systems}

In this study we use data from measurements with two lidar systems at IMK-IFU (until 2001 IFU, i.e., Institut für Atmosphärische Umweltforschung of the Fraunhofer Society; $47^{\circ} 28^{\prime} 37^{\prime \prime} \mathrm{N}, 11^{\circ} 3^{\prime} 52^{\prime \prime} \mathrm{E}, 730 \mathrm{~m}$ a.s.l.) and at the nearby high-altitude station Schneefernerhaus $\left(47^{\circ} 25^{\prime} 00^{\prime \prime} \mathrm{N}\right.$, $10^{\circ} 58^{\prime} 46^{\prime \prime} \mathrm{E}, 2675 \mathrm{~m}$ a.s.1.) on the south side of Mt Zugspitze ( $2962 \mathrm{~m}$ a.s.1.), about $6.5 \mathrm{~km}$ to the south-west of IMKIFU. The lidar system at IMK-IFU is an instrument of both NDACC and EARLINET. This system was originally built in 1973 (Impulsphysik GmbH), based on a ruby laser, and, in addition to a large number of routine and campaign-type tropospheric measurements (e.g., Reiter and Carnuth, 1975; 
Jäger et al., 1988, 2006; Forster et al., 2001; Trickl et al., 2003, 2011), has been almost continually used for measurements of stratospheric aerosol since autumn 1976 (e.g., Jäger, 2005; Deshler et al., 2006; Fromm et al., 2008b, 2010). The lidar was converted to a spatially scanning system with a Nd:YAG laser (Quanta Ray, GCR 4, $10 \mathrm{~Hz}$ repetition rate, about $700 \mathrm{~mJ}$ per pulse at $532 \mathrm{~nm}$ ) in the early 1990s for additional investigation of contrails (Freudenthaler, 2000; Freudenthaler et al., 1994, 1995). The $0.52 \mathrm{~m}$ Cassegrain receiver of the 1973 system was retained. For the routine measurements, the laser has been operated at the wavelength of $532 \mathrm{~nm}$ ever since. The stratospheric measurements discussed here have taken place during nighttime (vertical pointing; range: $2 \mathrm{~km}$ a.s.l. to more than $40 \mathrm{~km}$ a.s.l.) because of the necessity of single-photon counting and of reducing background signals. The vertical bins of this $300 \mathrm{MHz}$ multichannel scaler (FAST ComTec) are $75 \mathrm{~m}$ wide. Four subsequent measurements are made without attenuation and with three different attenuators, the strongest one being used for the near-field detection. A high-speed chopper is set to cut off the strongest part of the signal. For each attenuation step a different chopper delay is applied (minimum distance achieved: $1.3 \mathrm{~km}$ ). In the NDACC data base, following the format prescription, the data are not smoothed, which in the case of strong extinction leads to noise spikes in the lowest data segment within the tropopause region. With this lidar system, rather small aerosol structures exceeding roughly $2 \%$ of the Rayleigh return at $532 \mathrm{~nm}$ (that corresponds to a visual range of more than $400 \mathrm{~km}$ above $3 \mathrm{~km}$ ) can be resolved within the free troposphere and lower stratosphere. The aerosol backscatter coefficients can be calculated with a relative uncertainty of 10 to $20 \%$ under optimum conditions.

The backscatter coefficients have been calculated by iterative solution of the lidar equation. They are adjusted to match the Rayleigh backscatter coefficients at long distances, typically between 30 and $40 \mathrm{~km}$ a.s.l. In this procedure the atmospheric density is obtained from the routine radiosonde ascents at Oberschleißheim ("Munich radiosonde", station number 10868) and by using NCEP (National Centers for Environmental Prediction) meteorological data for the higher altitudes, daily interpolated for our station. The backscatter signals have been corrected for the light absorption by ozone in the stratosphere cross section for both the ruby wavelength (before 1990) and the wavelength of the frequency-doubled Nd:YAG laser (Brion et al., 1998; http: //igaco-o3.fmi.fi/ACSO/cross_sections.html). Climatological seasonally varying ozone profiles have been taken, obtained from the nearby Meteorological Observatory Hohenpeißenberg of the German Weather Service. The Rayleigh backscatter coefficients have been calculated from the very accurate algorithm provided by Owens (1967) and King factors obtained from a least-squares fit to the wavelength-dependent data by Bates (1984).

A number of aerosol measurements have been contributed by the water-vapour differential-absorption lidar (DIAL), op- erated at the Schneefernerhaus high-altitude research station. The full details of this lidar system were described by Vogelmann and Trickl (2008). This lidar system is based on a powerful tunable narrow-band Ti: sapphire laser system with up to $250 \mathrm{~mJ}$ (typically used: $100 \mathrm{~mJ}$ ) energy per pulse operated at $817.2 \mathrm{~nm}$ and a $0.65 \mathrm{~m}$-diameter Newtonian receiver. Due to these specifications a vertical range up to about $12 \mathrm{~km}$ is achieved, almost independent of time of day, with measurement durations of about fifteen minutes. The vertical resolution chosen in the data evaluation is dynamically varied between $50 \mathrm{~m}$ in altitude regions with good signal-to-noise ratio and roughly $250 \mathrm{~m}$ in the upper troposphere. The noise limit above $10 \mathrm{~km}$ a.s.l. corresponds to about $1.5 \times 10^{20} \mathrm{~m}^{-3}\left(\mathrm{H}_{2} \mathrm{O}\right.$ density $)$ or about $18 \mathrm{ppm}\left(\mathrm{H}_{2} \mathrm{O}\right.$ mixing ratio). Free-tropospheric measurements during dry conditions clearly benefit from the elevated site outside or just below the edge of the moist Alpine boundary layer (e.g., Carnuth and Trickl, 2000; Carnuth et al., 2002). After extensive testing, validating and optimizing the system, routine measurements were started in January 2007 with typically two measurement days per week, provided that the weather conditions are favourable. During this period also successful comparisons with an air-borne DIAL and a ground-based Fourier-transform infrared spectrometer were achieved, verifying the absence of a bias exceeding $1 \%$ (Wirth et al., 2009; Vogelmann et al., 2011).

The $817.2 \mathrm{~nm}$ measurements yielded additional information on the aerosol backscatter coefficients during a shutdown period of the NDACC lidar from May to September 2009 (EARLINET field campaign and construction work) and during some daytime period on 19 April 2010. Due to its power and its large receiver, this system has a rather wide range in the "off" wavelength channel reaching far into the stratosphere. However, since analogue data acquisition is used the signal quality starts to deteriorate in the far field due to electromagnetic interference and amplification noise. In particular, a small interference by the magnetic field caused by the flashlamp current of the Nd:YAG pump laser (Trickl, 2010) persists. This broad feature, lasting for several hundred microseconds, was determined from dark measurements, numerically smoothed and subtracted from the data, which resulted in noise-limited backscatter signals.

For the period in 2009 the $817.2 \mathrm{~nm}$ data with the best signal-to-noise ratio were taken. The Fernald-Klett method was applied (Fernald, 1984; Klett, 1985). The reference values were adjusted to yield optimum results at lower altitudes, e.g., in ranges without discernible aerosol, which was possible in several cases. In addition, the results from different measurements were verified to agree in altitude ranges without structures from fresh plumes. Due to the lower level of Rayleigh backscattering, the calibration of the aerosol backscatter coefficients is a more demanding task than at $532 \mathrm{~nm}$, and was done with particular care. The backscatterto-extinction ratio was chosen as $0.02 \mathrm{sr}^{-1}$, which is the climatological mean value found within EARLINET (e.g., 


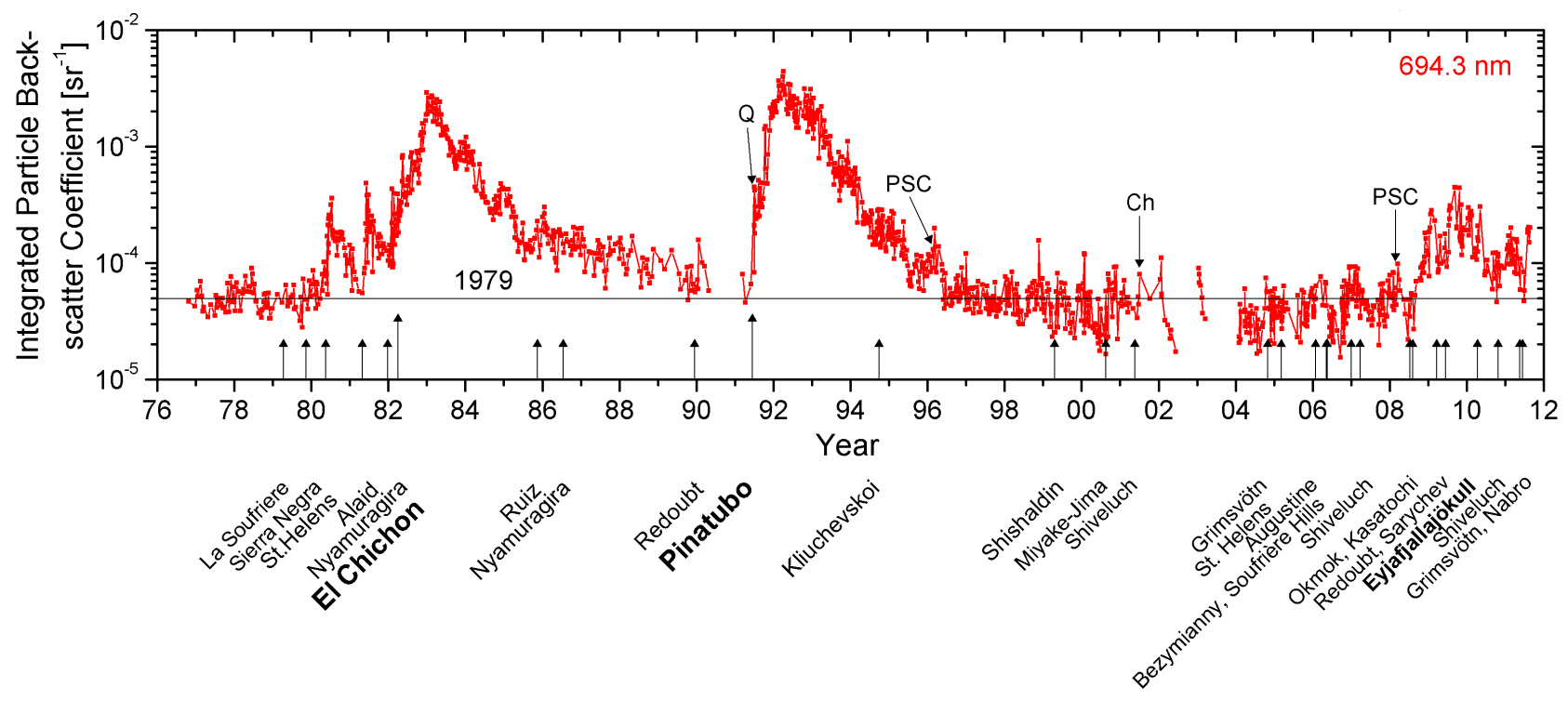

Fig. 1. Time series of the integrated stratospheric backscatter coefficient from the lidar measurements at Garmisch-Partenkirchen: the backscatter coefficients are integrated from $1 \mathrm{~km}$ above the tropopause to the upper end of the layer. Several minor events are marked in addition: two PSC observations, the Québec fire (Q) and the Chisholm fire (Ch).

Mattis et al., 2004). The data were converted to $532.26 \mathrm{~nm}$ by assuming a $\lambda^{-1.4}$ wavelength dependence (Jäger and Deshler, 2002, 2003) and then averaged within the standard $75 \mathrm{~m}$ vertical bins of the aerosol lidar. For the conversion of the Rayleigh backscatter coefficient a factor of 5.9605 was used, again derived from the algorithm by Owens (1967) and the data by Bates (1984). Because of narrow-band filtering of the DIAL return just the contribution of Raman Q branch was included, calculated from the King factor. The influence of ozone was neglected since the absorption cross section at $817 \mathrm{~nm}$ is $1 / 12$ of that at $532 \mathrm{~nm}$ (Brion et al., 1998; http: //igaco-o3.fmi.fi/ACSO/cross_sections.html).The final treatment was done with the standard procedure for the NDACC lidar, including the conversion to $694 \mathrm{~nm}$ traditionally performed for the integrated backscatter coefficients. The results for $532 \mathrm{~nm}$ were compared with those of the NDACC lidar within the neighbouring periods for additional quality control.

We frequently use the scattering ratio

$R=\frac{\beta_{\mathrm{R}}+\beta_{\mathrm{P}}}{\beta_{\mathrm{R}}}$,

with the Rayleigh and particle backscatter coefficients $\beta_{\mathrm{R}}$ and $\beta_{\mathrm{P}}$, respectively. Due to its normalization to the Rayleigh backscatter coefficients the scattering ratio gives a better idea of the "optical impact". Like a mixing ratio it also is independent of the number density of the air molecules. On the other hand the normalization by $\beta_{\mathrm{R}}$ (which is proportional to the air density) amplifies the noise of the data towards higher altitudes. Here, the high sensitivity of the big aerosol lidar is important.

\section{Results for the period 1976-2011}

The most recent version of the Garmisch-Partenkirchen time series of the integrated backscatter coefficient is shown in Fig. 1. The backscatter coefficients are integrated from $1 \mathrm{~km}$ above the tropopause (thermal tropopause of the midnight Munich radiosonde ascents, $100 \mathrm{~km}$ roughly to the north). The lower integration boundary was chosen above the tropopause because of the coarse range resolution before 1990 (600 m bins), potential contamination by cirrus clouds and uncertainties in the validity of the tropopause altitude for our site. The series is displayed here without errors for clearness. The errors were specified (for the shorter period until 1999) by Jäger (2005). Three major gaps exist caused by the breakdown of the ruby laser in 1990, field campaigns in 2002 and three severe system damages in 2003. Strong volcanic eruptions are marked by short vertical lines. Since 2000 also mid-latitude eruptions reaching altitudes of at least $12 \mathrm{~km}$ are included for supporting the discussion in this paper. Data with serious cloud contamination due to multiple scattering effects were identified (Reichardt and Reichardt, 2006) and removed from this figure. The series in Fig. 1 ends in August 2011 just before a complex system damage occurred that was not overcome before early September 2012.

In the following we describe some of the characteristics of different time periods.

\subsection{Results 1976-1996}

The time series is dominated by signals from the particles injected into the stratosphere by major volcanic eruptions, in particular those of El Chichon (Mexico, 1982) and 
Mt Pinatubo (Philippines, June 1991). The first volcanic aerosol peak observed in the stratosphere above GarmischPartenkirchen was that of Fuego (Guatemala, October 1974), seen during test measurements on 10 January 1975 (Reiter et al., 1979). This observation was made just with an oscilloscope, prior to the installation of adequate lidar detection electronics, and could, thus, not be evaluated quantitatively. As pointed out by Deshler (2008) this eruption, together with other, minor eruptions, influenced the aerosol level during the quasi-background period before 1980, and, thus, the results of our earliest measurements.

The volcanic aerosol after the El Chichon and Pinatubo peaks disappeared within about five years, the removal from the stratosphere being modulated in phase with the quasibiennial oscillation (Jäger, 2005).

\subsection{Background period 1997-2006}

During the background phase starting in 1997 the aerosol loading of the stratosphere was rather low (Fig. 1) and exhibited only very short elevated-aerosol events. On some days it was even difficult to resolve any aerosol component in the lidar signals received from the stratosphere. Until autumn 2006, the typical background scattering ratio was 1.02 to 1.05 , the layer ending at about $24 \mathrm{~km}$. One example is shown in Sect. 3.4. As during the volcanic periods some seasonal cycle is seen, caused by, e.g., the seasonal variation of the tropopause height or vertical exchange across the tropopause. There is no hint of an influence of the growing air traffic.

Hofmann et al. (2009) reported a positive trend of the stratospheric background in the Mauna Loa series after 1997 and ascribed it to the growing emissions from coal burning in China. We do not have evidence of a synchronous positive trend in our higher-latitude series although the northern part of China reaches the mid-latitudes. However, the minimum in the background does not occur before the second half of 2000, i.e., later than the minimum in the Mauna Loa record. For comparison, the delay between eruption and peak observed in our series for El Chichon and Pinatubo was just about half a year. It is not possible to localize the minimum exactly due to some structure occurring after the Miyake Jima eruption and the Chisholm fire (see following section) as well as due to the data gaps in 2002 and 2003. In any case, the SAGE II results in Fig. 3 of Vernier et al. (2011b) for $20^{\circ}$ to $50^{\circ} \mathrm{N}$ (20 to $30 \mathrm{~km}$ a.s.l.) support the absence of a positive trend: between June 2000 and autumn 2004 the SAGE II aerosol optical depths, despite the large latitudinal range, do not exhibit any relevant increase, some small growth being seen just in 2005 and 2006.

Although some small anthropogenic influence cannot be excluded, it is more reasonable to discuss the differences between the observations at our site and at low latitudes by comparing the differing volcanic activity in the two latitude ranges (see also Vernier et al., 2011b). Assuming that midlatitude eruptions are more important for our observations, we have summarized in Table 1 events within $\pm 17^{\circ}$ from our latitude that at least reach $10 \mathrm{~km}$. This altitude is a good estimate for the lowest tropopause positions (Pan et al., 2004), $12 \mathrm{~km}$ (bold numbers in Table 1) being a typical summertime value of the tropopause altitude. Table 1 is mostly based on the comprehensive listing of the eruptions routinely updated by Massie (2012) for the period starting in 2004, but also other sources specified in Table 1. The number of eruptions per year reaching at least $10 \mathrm{~km}$ has almost steadily grown since 2000. However, the integrated backscatter coefficients in Fig. 1 do not rise strongly before 2008, when the strongest eruptions, as judged from the top altitude and volcanic explosivity index (VEI; Newhall and Self, 1982), occurred (with just one questionable exception, Shiveluch, 2001; see remark in Table 1). This agrees well with an earlier conclusion that a minimum VEI of 4 is required for discernible stratospheric impact (Deshler, 2008). This conclusion does not exclude the presence of short-lived (i.e., not accumulating) aerosol structures from the less important events (see Sect. 3.4 for one example that could be assigned: Redoubt, 2009).

In the tropics the most frequent tropopause altitudes start at about $14.5 \mathrm{~km}$ (Pan et al., 2004). Nevertheless, there was a significant year-by-year rise in eruptions reaching at least the much higher upper troposphere prior to the rise in the mid-latitudes. Explicitly, in the listings of Massie (2012) we found eleven eruptions between $20^{\circ} \mathrm{S}$ and $20^{\circ} \mathrm{N}$ reaching at least $15 \mathrm{~km}$ between 2004 and 2008, five of which ending at least at $18 \mathrm{~km}$. As discussed in Sect. 5, a trend component caused by aerosol transfer from the upper troposphere to the stratosphere must be considered at low latitudes. However, by analysing satellite-based measurements, Vernier et al. (2011b) concluded a stepwise increase of the aerosol between $20^{\circ} \mathrm{S}$ and $20^{\circ} \mathrm{N}$ from some of the strongest eruptions alone.

The discussion of the fate of eruptions just reaching the tropopause region in the mid-latitudes is resumed with the description of the results for the Eyjafjallajökull eruption (Sect. 4).

\subsection{Non-volcanic sources of stratospheric aerosol}

\subsubsection{Influence of fires}

During the period covered by our measurements there were three periods with low to moderate volcanic influence in the stratosphere. In the longest period of this kind, the background period since the late 1990s, the influence of less important sources of stratospheric aerosol can be distinguished. One important source could be strong forest fires, a topic with growing importance on the way to a drier climate. In fact, the area burnt per year in the United States, where longterm statistics exist, has roughly doubled since the 1990s (Fig. 2).

In particular, so-called pyro-cumulonimbus (pyroCb) clouds reach the stratosphere and give rise to aerosol 
Table 1. List of volcanic eruptions $\pm 17^{\circ}$ distant in latitude from Garmisch-Partenkirchen and reaching at least 10 km (2000-2011); numbers in bold highlight top altitudes of $12 \mathrm{~km}$ and more. The information was extracted from Massie (2012), and between 2000 and April 2004 from http://www.volcano.si.edu, as well as other sources. MPA: maximum plume altitude; VEI: volcanic explosivity index (sources: Siebert et al., 2010, and http://www.volcano.si.edu (subsection: eruptive history of single volcanoes)).

\begin{tabular}{|c|c|c|c|c|}
\hline Date/Period & Volcano & Location & MPA $[\mathrm{km}]$ & VEI \\
\hline 18 August 2000 & Miyake-Jima & Japan, $34.08^{\circ} \mathrm{N}$ & $16^{1}$ & 3 \\
\hline 19 February 2001 & Cleveland & Aleutian Islands, $52.82^{\circ} \mathrm{N}$ & $>10$ & 3 \\
\hline 22 May 2001 & Shiveluch & Kamchatka, $56.65^{\circ} \mathrm{N}$ & 20 & $4 ?^{2}$ \\
\hline 7 August 2001 & Bezymianny & Kamchatka, $55.9^{\circ} \mathrm{N}$ & 10 & 3 \\
\hline 26 July 2003 & Bezymianny & Kamchatka, $55.9^{\circ} \mathrm{N}$ & $8-11$ & 3 \\
\hline 9-12 May 2004 & Shiveluch & Kamchatka, $56.65^{\circ} \mathrm{N}$ & 11 & 3 \\
\hline 19 June 2004 & Bezymianny & Kamchatka, $55.9^{\circ} \mathrm{N}$ & 10 & 3 \\
\hline 1 November 2004 & Grimsvötn & Iceland, $64.42^{\circ} \mathrm{N}$ & 12 & 3 \\
\hline 11 January 2005 & Bezymianny & Kamchatka, $55.9^{\circ} \mathrm{N}$ & 10 & 3 \\
\hline 8 March 2005 & St. Helens & Washington, $46.2^{\circ} \mathrm{N}$ & 11 & $(30 \mathrm{~min})$ \\
\hline 6-7 July 2005 & Shiveluch & Kamchatka, $56.65^{\circ} \mathrm{N}$ & 10 & n.a. ${ }^{2}$ \\
\hline 11, 13 January 2006 & Augustine & Alaska, $59.36^{\circ} \mathrm{N}$ & 10.4 & 3 \\
\hline 27,30 January 2006 & Augustine & Alaska, $59.36^{\circ} \mathrm{N}$ & 12.2 & n.a. ${ }^{2}$ \\
\hline 9 May 2006 & Bezymianny & Kamchatka, $55.9^{\circ} \mathrm{N}$ & 15 & 3 \\
\hline 24 December 2006 & Bezymianny & Kamchatka, $55.9^{\circ} \mathrm{N}$ & 10 & 3 \\
\hline 16-28 December 2006 & Shiveluch & Kamchatka, $56.65^{\circ} \mathrm{N}$ & 10 & n.a. ${ }^{2}$ \\
\hline 1-26 January 2007 & Shiveluch & Kamchatka, $56.65^{\circ} \mathrm{N}$ & 13.7 & n.a. ${ }^{2}$ \\
\hline 29-30 March 2007 & Shiveluch & Kamchatka, $56.65^{\circ} \mathrm{N}$ & 12.2 & n.a. ${ }^{2}$ \\
\hline 9-11 June 2007 & Kliuchevskoi & Kamchatka, $56.0^{\circ} \mathrm{N}$ & 11 & 2 \\
\hline 3-21 August 2007 & Shiveluch & Kamchatka, $56.65^{\circ} \mathrm{N}$ & 10 & n.a. ${ }^{2}$ \\
\hline 12 July 2008 & Okmok & Aleutian Islands, $53.43^{\circ} \mathrm{N}$ & 15 & $4 ?$ \\
\hline 17-30 July 2008 & Okmok & Aleutian Islands, $53.43^{\circ} \mathrm{N}$ & 12.2 & n.a. ${ }^{2}$ \\
\hline 2-5 August 2008 & Okmok & Aleutian Islands, $53.43^{\circ} \mathrm{N}$ & 10.7 & n.a. ${ }^{2}$ \\
\hline 7-9 August 2008 & Kasatochi & Aleutian Islands, $52.17^{\circ} \mathrm{N}$ & 13.7 & 4 \\
\hline 22-23 March 2009 & Redoubt & Alaska, $60.48^{\circ} \mathrm{N}$ & 19.8 & 3 \\
\hline 4-7 April 2009 & Redoubt & Alaska, $60,48^{\circ} \mathrm{N}$ & 15.2 & n.a. ${ }^{2}$ \\
\hline 16 June 2009 & Sarychev & Kuril Islands, $48.09^{\circ} \mathrm{N}$ & $9.7(\mathbf{1 2 - 1 8})$ & 4 \\
\hline 15 October 2009 & Ebeko & Kuril Islands, $50.68^{\circ} \mathrm{N}$ & 10.7 & $?$ \\
\hline 17 December 2009 & Bezymianny & Kamchatka, $55.9^{\circ} \mathrm{N}$ & 10 & $3 ?$ \\
\hline 22-23 January 2010 & Kliuchevskoi & Kamchatka, $56.0^{\circ} \mathrm{N}$ & 10.1 & 2 \\
\hline 14-15 April 2010 & Eyjafjallajökull & Iceland, $63.6^{\circ} \mathrm{N}$ & $\geq 8^{4}$ & 4 \\
\hline 1 June 2010 & Bezymianny & Kamchatka, $55.9^{\circ} \mathrm{N}$ & 10 & 3 \\
\hline $1-11$ October 2010 & Kliuchevskoi & Kamchatka, $56.0^{\circ} \mathrm{N}$ & 10.1 & n.a. ${ }^{2}$ \\
\hline 28 Oct-14 Nov 2010 & Shiveluch & Kamchatka, $56.65^{\circ} \mathrm{N}$ & 12 & n.a. ${ }^{2}$ \\
\hline 13 December 2010 & Kizimen & Kamchatka, $55.13^{\circ} \mathrm{N}$ & 10 & 3 \\
\hline 23-25 January 2011 & Kizimen & Kamchatka, $55.13^{\circ} \mathrm{N}$ & 10 & n.a. \\
\hline 18 April 2011 & Karymski & Kamchatka, $55.4^{\circ} \mathrm{N}$ & 11.9 & $3^{2}$ \\
\hline 3-4 Мay 2011 & Kizimen & Kamchatka, $55.13^{\circ} \mathrm{N}$ & 10 & $?$ \\
\hline 21-24 May 2011 & Grimsvötn & Iceland, $64.42^{\circ} \mathrm{N}$ & 20 & $\geq 4^{5}$ \\
\hline 27-31 May 2011 & Shiveluch & Kamchatka, $56.65^{\circ} \mathrm{N}$ & 10 & n.a. ${ }^{2}$ \\
\hline 3-21 June 2011 & Shiveluch & Kamchatka, $56.65^{\circ} \mathrm{N}$ & 10 & n.a. ${ }^{2}$ \\
\hline 9-15 September 2011 & Shiveluch & Kamchatka, $56.65^{\circ} \mathrm{N}$ & 10.3 & n.a. ${ }^{2}$ \\
\hline 13-21 October 2011 & Shiveluch & Kamchatka, $56.65^{\circ} \mathrm{N}$ & 10.6 & n.a. ${ }^{2}$ \\
\hline
\end{tabular}

1 From (Nakada, 2005)

2 The eruptive history in http://www.volcano.si.edu seems

to specify the long period 1999-2011 for the Shiveluch 2001 VEI and extended periods also for the other data flagged by this footnote.

${ }^{3}$ From http://www.volcanodiscovery.com/sarychev.html; the eruption maximum is reported here for 15 June.

${ }^{4}$ Radar measurements show a maximum of $9.5 \mathrm{~km}(9.3 \mathrm{~km})$ at the beginning and more than $8 \mathrm{~km}$ several times until early 18 April (Petersen, 2010; Arason et al., 2011).

${ }^{5}$ From http://en.wikipedia.org/wiki/List_of_large_volcanic_eruptions_in_the_21st_century. 


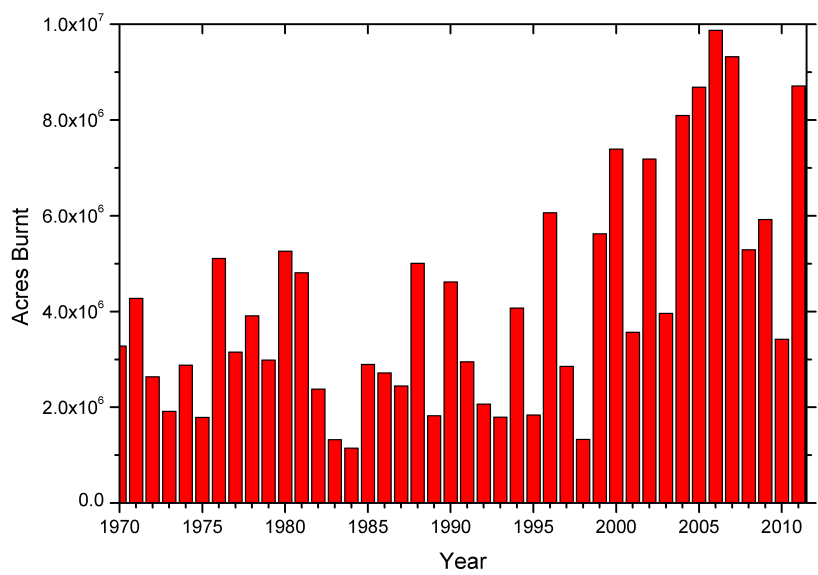

Fig. 2. Number of acres burnt per year in the United States of America (1960-2011); the numbers were taken from the National Interagency Fire Center (http://www.nifc.gov/).

observations above the tropopause. Two pyroCb events that yielded also plume observations at GarmischPartenkirchen were recently studied in an international co-operation (Fromm et al., 2008b, 2010; see marks in Fig. 1). The first is the Chisholm fire, initiating a huge burst of smoke that occurred over Northern Canada on 28 May 2001. The plume was sufficiently intense to be followed with TOMS satellite images (http://toms.gsfc.nasa.gov/aerosols/aerosols.html, recently moved to http://ozoneaq.gsfc.nasa.gov/earthProbeAerosol. md) all the way across the North Atlantic. However, it missed Garmisch-Partenkirchen during the first approach. The plume was observed with some delay during the second half of June and in early July.

The Chisholm particles gradually filled the lowermost stratosphere in the entire Northern Hemisphere, as determined from observations with satellites and with NDACC lidar systems (Fromm et al., 2008b). The integrated backscatter coefficient in Fig. 1 just doubled after the arrival of the Chisholm plume. By the end of that year the amount of aerosol in the stratosphere started to drop considerably, which sets an ultimate limit also to the Chisholm period above our station. Although a systematic assessment of the impact of pyroCbs is still missing, the observations for this particularly violent event suggest that the contribution of biomass burning is small in comparison with that of major volcanic eruptions.

The situation can be different for direct advection of a pyroCb plume. This was the case for the second pyroCb event studied in detail that took place in the Québec province (Canada) in June 1991 (Fromm et al., 2010). The plume was observed directly after the first passage across the Atlantic and, therefore, yielded much more pronounced signatures in the lower stratosphere than the Chisholm case. Measurements were made with both the NDACC lidar (during the first

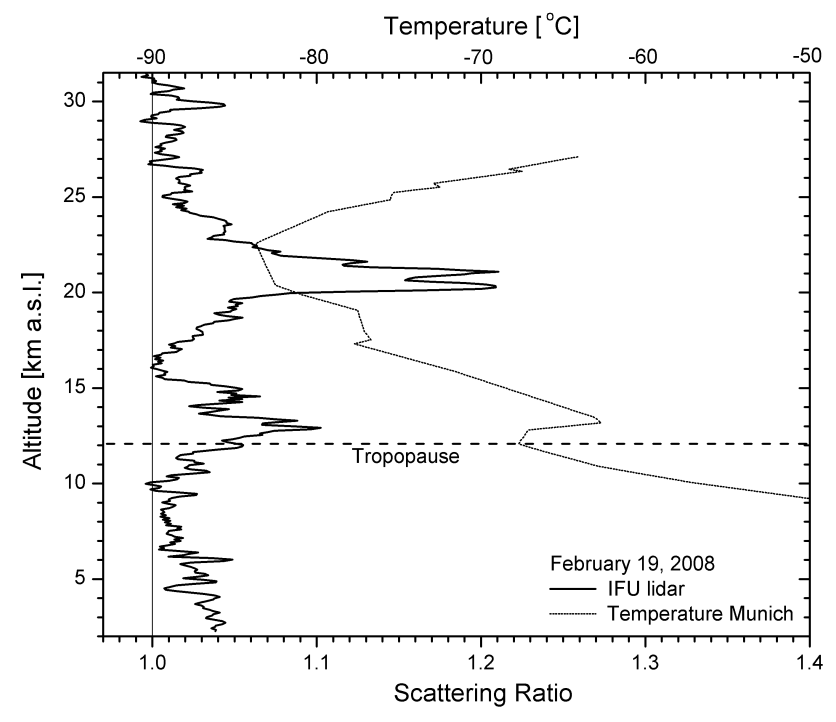

Fig. 3. Polar stratospheric cloud observed over GarmischPartenkirchen at about $21 \mathrm{~km}$ on 19 February $2008(532 \mathrm{~nm})$.

night hour of 1 July 1991) and the IFU tropospheric ozone lidar (extended time series between 1 and 3 July; see also Carnuth et al., 2002). The maximum backscatter coefficient at $313 \mathrm{~nm}$ was as high as $8.4 \times 10^{-6} \mathrm{~m}^{-1} \mathrm{sr}^{-1}$, at $15 \mathrm{~km}$. This corresponds to an aerosol-related horizontal visual range at $313 \mathrm{~nm}$ of roughly $9 \mathrm{~km}$. The lower-stratospheric plume had been initially misinterpreted as the first arrival of Mt Pinatubo aerosol over Garmisch-Partenkirchen (Carnuth et al., 2002; beginning of the eruption: 12 June 1991), but this possibility was clearly rejected by extensive trajectory calculations (Fromm et al., 2010).

\subsubsection{Polar stratospheric clouds}

Polar stratospheric clouds (PSCs) are normally observed in the polar regions. However, the Arctic polar vortex sometimes stretches to mid-latitudes (e.g., Teitelbaum et al., 2001) and PSCs have been occasionally observed as far south as Southern France (Keckhut et al., 2007). Over GarmischPartenkirchen (lidar: $47.477^{\circ} \mathrm{N}$ ) PSC events were observed on 5 March 1996 (see also Keckhut et al., 2007, and Hervig, 1999) and on 19 February 2008 (Fig. 3). Both cases are marked in Fig. 1. The Munich radiosonde reveals pronounced temperature troughs between 19 and $23 \mathrm{~km}$ in both cases. The minimum temperatures registered around the PSC altitudes were $-80.3{ }^{\circ} \mathrm{C}$ and $-83.7^{\circ} \mathrm{C}$ for these two cases, respectively. The Arctic origin of the air masses was verified by $315 \mathrm{~h}$ HYSPLIT backward trajectories (Draxler and Hess, 1998; http://ready.arl.noaa.gov/HYSPLIT_traj.php) initiated above our lidar site in the evening of both days. The PSCs observed over Garmisch-Partenkirchen were rather narrow and, thus, did not contribute significantly to the integrated 


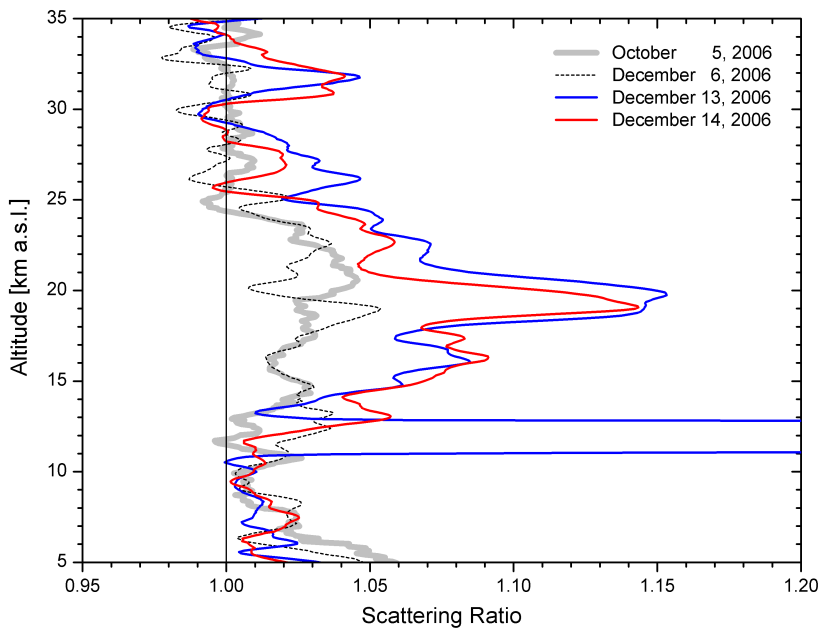

Fig. 4. $532 \mathrm{~nm}$ scattering ratios from December 2006 showing the sudden rise in stratospheric loading after a long background period characterized by values between 1.02 and 1.05, i.e., $2-4 \%$ above Rayleigh conditions. A profile from 5 October 2006 is included showing an aerosol cut-off at about $24.5 \mathrm{~km}$. The profiles are smoothed by seven-point (December) or eleven-point (October) averaging.

backscatter coefficients. Nevertheless, they represented local maxima in the time series shown in Fig. 1.

\subsubsection{Mineral dust}

The occasional presence of mineral dust from deserts in Africa and Asia in the lower stratosphere is documented in Sect. 4.

\subsection{Increase of volcanic activity between 2006 and 2011}

Starting in 2006, a number of significantly stronger eruptions occurred that ended the background period for our site. The first one was that of the Soufrière Hills volcano (Caribbean Sea; 20 May 2006), which reached $16.8 \mathrm{~km}$ (Massie, 2012). This event took place in the tropics and, therefore, just led to a minor rise in the integrated backscatter coefficients in Fig. 1. We ascribe the temporary aerosol event in December 2006 (Fig. 4) to this eruption. As seen in Fig. 4, the stratosphere was loaded with aerosols exceeding the 2006 background up to $30 \mathrm{~km}$ or more by a factor of two to four for a few days. The wide vertical distribution of the stratospheric particles above our site suggests a considerable age of that plume, in agreement with the much earlier eruption date. The entire ensemble of $315 \mathrm{~h}$ stratospheric HYPSLIT backward trajectories calculated for the measurement days in December 2006 (up to $25 \mathrm{~km}$ ) ended at lower latitudes of the Northern Hemisphere. The Soufrière Hills plume stayed in the tropics for some time (Prata et al., 2007; Vernier et al., $2011 b$ ). Our observation is consistent with a rather delayed northward export of a portion of these aerosols. Figure 2 of
Vernier et al. (2011b) confirms our view and shows the vertical expansion of the plume within the tropics to the altitude range of our observations.

We also examined other possibilities; however, no major volcanic eruption or wild fires could be identified during the two months preceding these observations. Significant midlatitude eruptions had not taken place since 9 May (Bezymianny, Kamchatka; top of plume: $15 \mathrm{~km}$; see Table 1). A potential source is the eruption of Rabaul (New Guinea) on 7 October 2006, which reached $18 \mathrm{~km}$. However, this eruption was short, occurred in the Southern Hemisphere $\left(4.27^{\circ} \mathrm{S}\right)$, and the plume propagated farther to the south. Also a PSC event could be ruled out due to temperatures not below $-70{ }^{\circ} \mathrm{C}$ between 12 and $25 \mathrm{~km}$ a.s.l.

The most important change occurred in 2008 and 2009 when several strong eruptions occurred in the mid-latitudes (Table 1; Massie, 2012; Martinsson et al., 2009; Bourassa et al., 2010; Heue et al., 2010; Mattis et al., 2010; Kravitz et al., 2011; Campbell et al., 2012), starting with those of the Aleutian volcanoes Okmok and Kasatochi (both VEI = 4). In Figs. 5 and 6 we give a few examples from the most spectacular period, May to September 2009, related to the eruptions of Redoubt (Alaska, VEI = 3) and Sarychev (Kuril Islands, VEI = 4). The data are from the Zugspitze DIAL system since the stratospheric lidar could not be operated during this period (Sect. 2.1).

Between 5 May and 30 June 2009, some spikes were detected between the tropopause (varying between 11 and $12 \mathrm{~km}$ ) and about $14 \mathrm{~km}$ (Fig. 5). This temporary structure was tentatively assigned to the Redoubt eruption, HYSPLIT giving clear evidence on 26 May. A part of the Redoubt aerosol structure in the June examples was most likely advected also below the thermal tropopause, in agreement with the idea of a "mixing zone" around the thermal tropopause (e.g., Gettelman et al., 2011). This interpretation is supported by the fact that on 5 and 30 June the relative humidity $(\mathrm{RH})$ for both the Munich and the Innsbruck (37 km to the southeast; launches at 03:00 UTC) radiosonde stayed below 50\% above $8.5 \mathrm{~km}$, which suggests the absence of cirrus clouds in the uppermost troposphere. The stratospheric structure disappeared before the arrival of the Sarychev plume.

The Sarychev plume was first observed above GarmischPartenkirchen on 14 July and exhibited several thin layers between $14 \mathrm{~km}$ and $19 \mathrm{~km}(R \leq 2.2)$. Figure 6 shows three examples of profiles from different periods in the plume development. A separate spike ( $R=2.5$ on 16 July) was observed both on 14 and 16 July, centred at $22.5 \mathrm{~km}$ and $21.7 \mathrm{~km}$, respectively. During the first months a pronounced intraday variability of the structure was observed. The highest values $\left(R \approx 2.4\right.$, converted to $\beta_{\mathrm{P}} \approx 3 \times 10^{-7} \mathrm{~m}^{-1} \mathrm{sr}^{-1}$ at about $17 \mathrm{~km}$ ) occurred by the end of July and in August. Towards the end of September 2009 a transition to a smoother distribution occurred that continued to be present into the following year. The top $532 \mathrm{~nm}$ scattering ratio extended to more than $1.4\left(\beta_{\mathrm{P}} \approx 1 \times 10^{-7} \mathrm{~m}^{-1} \mathrm{sr}^{-1}\right.$ at about $\left.16 \mathrm{~km}\right)$ by the 


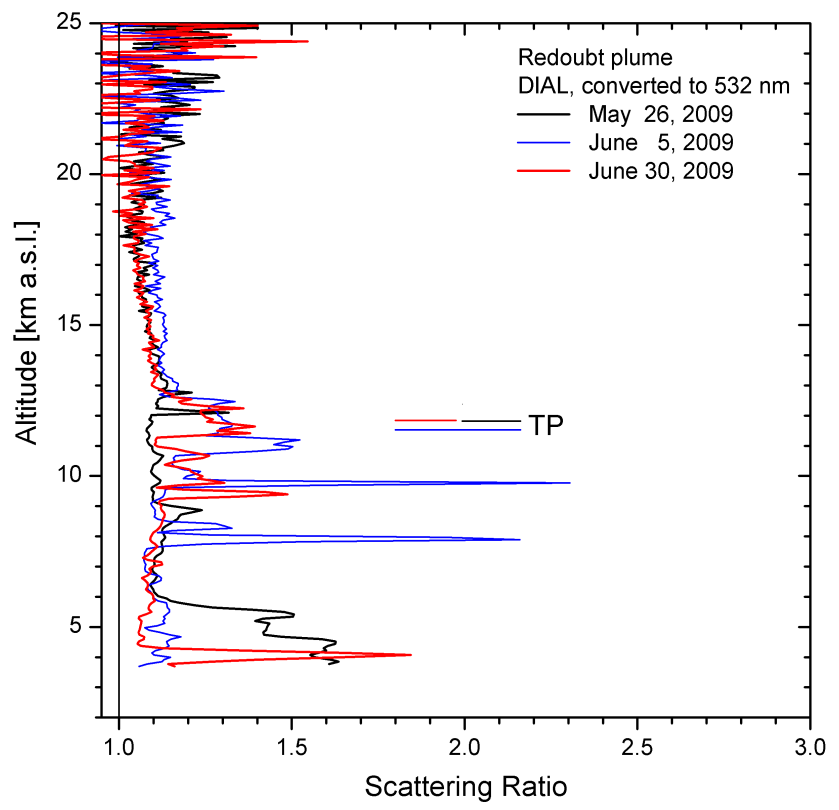

Fig. 5. Examples of $532 \mathrm{~nm}$ scattering ratios from the DIAL in May and June 2009, showing the signature of the Redoubt plume; the strong increase in noise and uncertainty above $15 \mathrm{~km}$ is due to the normalization to density (division by Rayleigh backscatter coefficients, see Sect. 2 for details). The tropopause levels (TP) are marked in the same colours as the corresponding scattering ratios. On 5 and 30 June, some of the Redoubt particles were also detected below the Munich thermal tropopause. The spikes below $8.5 \mathrm{~km}$ could be due to cirrus clouds; those between 9 and $10 \mathrm{~km}$ cannot be assigned.

end of September 2009 and gradually diminished to 1.15 in February 2010, about 1.1 in April (before the Eyjafjallajökull eruption, Sect. 4) and 1.07 in July. During this period the layer widened to a plateau that extended to $28 \mathrm{~km}$ by the end of June 2010, the aerosol layer ending at $30 \mathrm{~km}$, and then gradually shrunk in vertical extent. The behaviour qualitatively agrees with that for $1064 \mathrm{~nm}$ reported by Mattis et al. (2010) for Leipzig during the period 2008-2009. However, the infrared values seem to be rather low, which indicates small particles (one August example for $532 \mathrm{~nm}$ being in relatively good agreement with our results). Indeed, Mattis et al. (2010) derived an effective radius of $0.2 \mu \mathrm{m}$ and Ångström coefficients up to 2.

It is important to note that the decay time for the Sarychev aerosol is considerably shorter than that for the El Chichon and Pinatubo eruptions. This indicates a faster removal of the particles from the mid-latitude lower stratosphere (see Sect. 5).

The top altitude of the Sarychev eruption is listed in the "Summary of volcanic activity" (Massie, 2012) as just $10 \mathrm{~km}$ (Table 1), in clear disagreement with our observations. Kravitz et al. (2011) quote a much higher altitude of $16 \mathrm{~km}$ (the "mushroom" in their Fig. 1, taken from space, is impres-

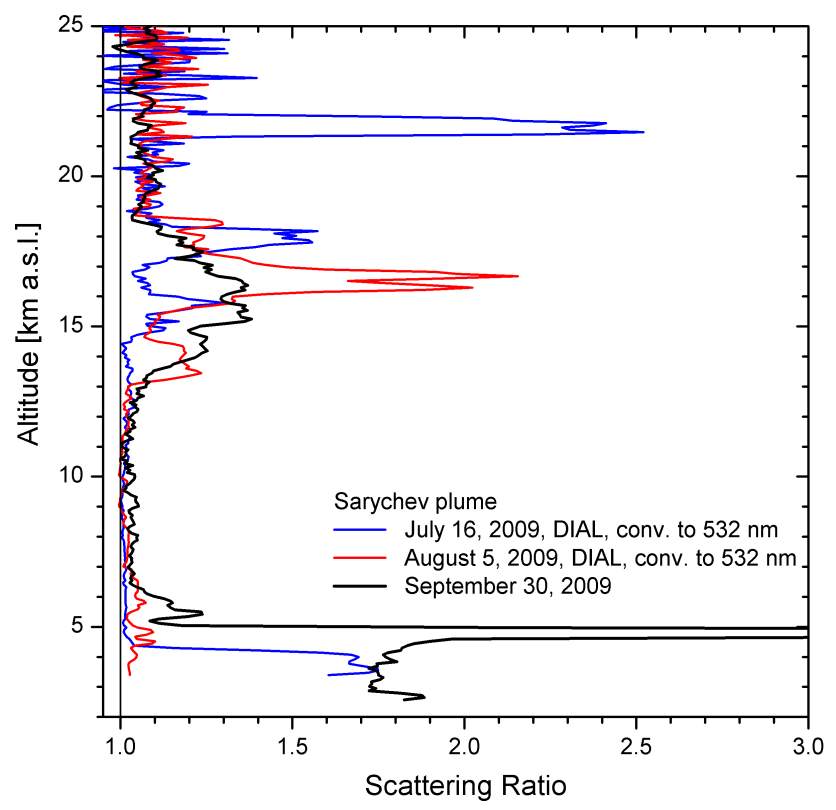

Fig. 6. Examples of $532 \mathrm{~nm}$ scattering ratios in from July to September 2009, showing the signature of the Sarychev plume; the signal of the NDACC lidar was low in the third example due to pronounced light extinction in the aerosol layer below $5 \mathrm{~km}$ and is, therefore, averaged between 6.3 and $12 \mathrm{~km}$ to reduce the noise.

sive), and sources on the Internet suggest much higher altitudes up to $18 \mathrm{~km}$. In order to verify this we analysed aerosol images from the space-borne lidar CALIOP (Cloud-Aerosol LIdar with Orthogonal Polarization) onboard the CALIPSO (Cloud-Aerosol Lidar and Infrared Pathfinder Satellite Observation) satellite for an extended period of time (http: //www-calipso.larc.nasa.gov/). A westward component was observed at altitudes up to $23.5 \mathrm{~km}$ over East Siberia, and a faster eastward plume was found between 15 and $18 \mathrm{~km}$ south of Alaska and later over western North America - in excellent agreement with our observations. Both components were verified by $315 \mathrm{~h}$ forward and backward HYSPLIT trajectories, started above the volcano (16 June) and GarmischPartenkirchen (16 July, see Fig. 6), respectively. In contrast to the Eyjafjallajökull plume described in the following section the Sarychev aerosols were not depolarizing which indicates spherical particles in some agreement with the idea of a condensation of $\mathrm{SO}_{2}$ as an important aerosol source (Kravitz et al., 2011).

\section{Eyjafjallajökull 2010, and beyond}

The Icelandic volcano Eyjafjallajökull started to erupt on 14 April 2010. Within an anti-cyclonic air stream the ash plume headed for Central Europe, a unique target for coordinated lidar sounding by EARLINET. After receiving first news about the eruption on the radio the EARLINET stations 


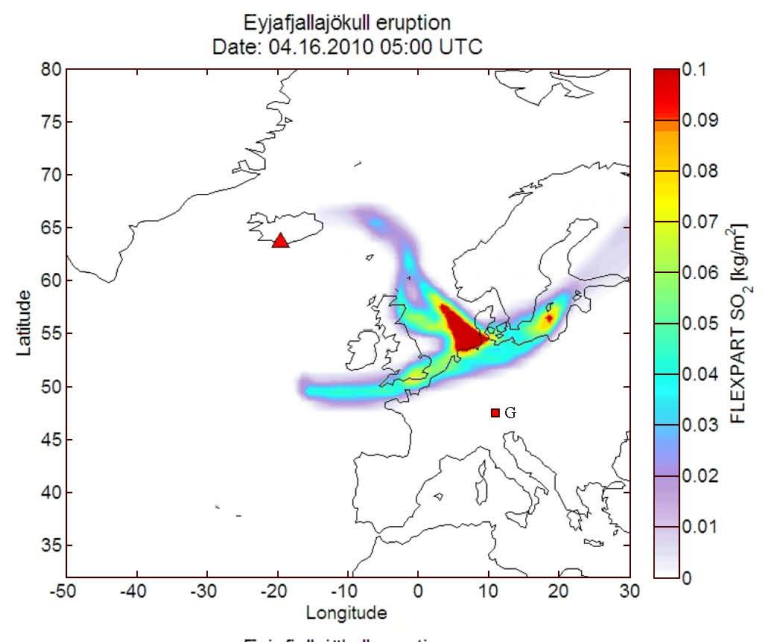

Eyjafjallajökull eruption

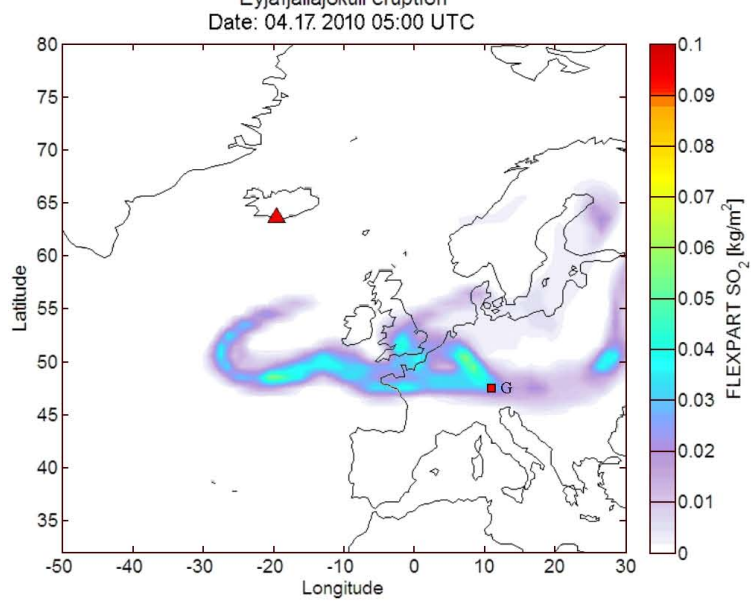

Eyjafjallajökull eruption

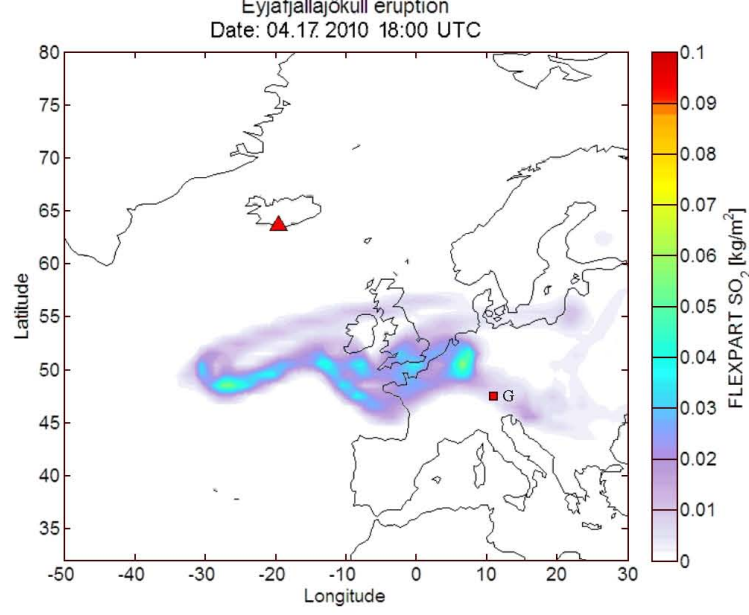

Fig. 7. Examples from calculations with the FLEXPART dispersion model carried out on 21 April 2010 (source: N. Kristiansen and S. Eckhardt, NILU, Norway); the eruption period chosen in the simulation was 14 April, 18:00 UTC, to 15 April, 18:00 UTC. The images show $\mathrm{SO}_{2}$ mass columns. The position of Eyjafjallajökull is marked by a red triangle, that of Garmisch-Partenkirchen (G) by a red square. were independently warned by us and the EARLINET team in Potenza in the early afternoon of 15 April, well before the ash plume reached the coast of the North Sea on Friday, 16 April, and the Alps on Saturday, 17 April (Fig. 7). Due to a low-pressure zone over Northern Italy the volcanic ash did not travel beyond the Alps. Thus, Garmisch-Partenkirchen was the southernmost EARLINET station detecting the main part of the ash plume during its first approach.

The anti-cyclonic air stream strongly descended and was, slightly before the eruption, accompanied by a stratospheric air intrusion starting over Greenland and Iceland, forecasted by the operational four-day trajectory plots we daily receive from ETH Zürich (e.g., Zanis et al., 2003; Trickl et al., 2010). The subsidence of the ash layer observed over Leipzig, Maisach and Hohenpeißenberg (Ansmann et al., 2010; Flentje et al., 2010; Gasteiger et al., 2011) resembles that typically observed for stratospheric air intrusions in our area (e.g., Eisele et al., 1999; Zanis et al., 2003; Trickl et al., 2010), indicating a similar transversely sloped geometry.

For several days, ash reached the northern rim of the Alps. The detection with the lidar systems at GarmischPartenkirchen, in contrast to those at Hohenpeißenberg (38 km to the north; Flentje et al., 2010) and Maisach close to Munich (Ansmann et al., 2010; Gasteiger et al., 2011), was impeded by frequent clouds and, in part, rain due to repetitive low pressure over Italy or convective conditions. The only exception was 19 April, when clear conditions prevailed and also made possible daytime measurements with the watervapour DIAL. The arrival of the ash could not be determined visually because of reduced visibility on and before 17 April. Also mostly because of truly bad weather conditions just a single early-night measurement with the NDACC lidar was made in May (on 9 May).

In the following subsections both the observational data and the analysis for the period between 17 and 23 April are presented. We describe the results for both the troposphere and the stratosphere. Starting on 20 April the complexity of the aerosol contributions in the entire range increased considerably, which required very detailed analyses.

\subsection{Radiosonde and radar data}

Table 2 shows the tropopause altitude and maximum uppertropospheric relative humidity from the radiosonde ascents at the stations Keflavik (Iceland) and Munich $(100 \mathrm{~km}$ north of our site) for 13 to 23 April 2010 (http://weather.uwyo. edu/upperair/sounding.html). Due to the sometimes complex temperature distribution, we define the tropopause as the first temperature inversion close to the final drop in relative humidity towards the stratosphere. The values stay below $10 \mathrm{~km}$ for the most important period between 14 and 17 April. During most of our observational period the tropopause was approximately $10 \mathrm{~km}$ also above Munich.

The maximum eruption altitude is specified as " $>8 \mathrm{~km}$ " by Massie (2012). Petersen (2010) and Arason et al. (2011) 


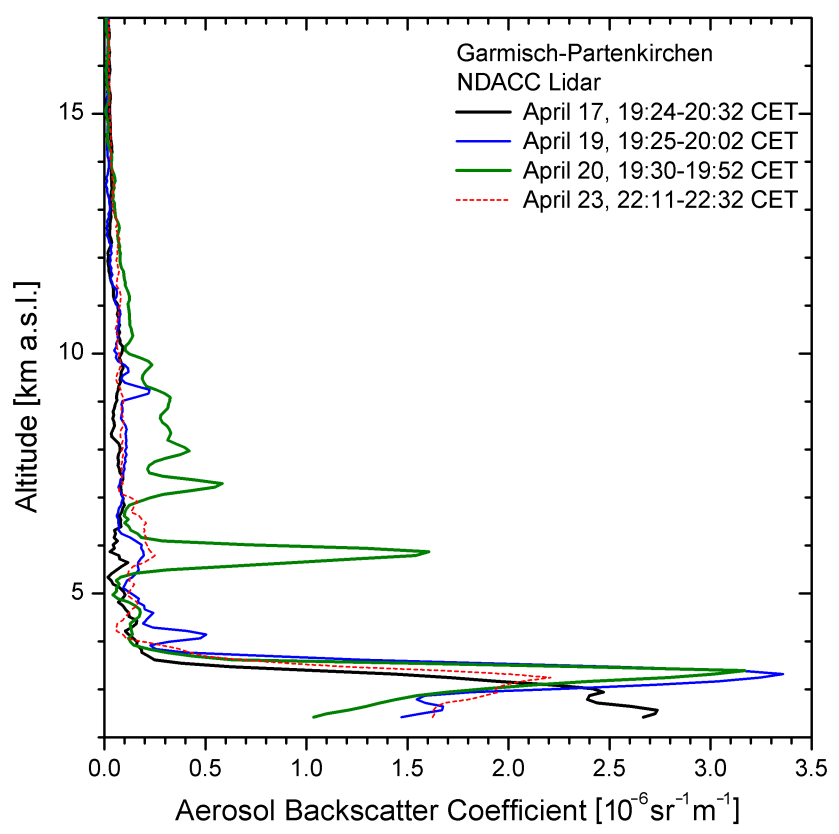

Fig. 8. The $532 \mathrm{~nm}$ aerosol backscatter coefficients from the NDACC lidar on all four relevant measurement evenings in April 2010. Three-point arithmetic averaging was applied for reducing the noise.

display time series of the eruption altitude based on radar measurements. The highest altitude in Fig. 9 of Arason et al., $9.3 \mathrm{~km}$, is given for the early afternoon of 14 April, and is associated with the first eruption peak and slightly above the Keflavik 12:00 UTC tropopause (Table 2). The true top value could be even slightly higher because of the radar scans were carried out for discrete elevation angles. Peak altitudes between 8.0 and $8.7 \mathrm{~km}$ are repeatedly marked between 16 April and early 18 April, the period most important for our observations. On 18 and 19 April, the peak altitude dropped, oscillating between 2 and $5 \mathrm{~km}$.

The tropopause values for Keflavik are occasionally even lower than the maximum altitudes reached by the eruption. Additionally, one cannot exclude that some of the hot gas from the eruption, condensing or loaded with a certain fraction of small particles, rose to $10 \mathrm{~km}$ and higher without being detected.

\subsection{Observations at Garmisch-Partenkirchen}

The results for all four measurement nights with the NDACC lidar are shown in Figs. 8 and 9, those for the DIAL in the late afternoon of 19 April in Fig. 10. In addition, we show in Fig. 11 a water-vapour profile obtained from the same measurements underlying Fig. 10. The main part of the ash was observed below $4 \mathrm{~km}$ on all days, with backscatter coefficients between $2.2 \times 10^{-6} \mathrm{~m}^{-1} \mathrm{sr}^{-1}$ and $3.4 \times 10^{-6} \mathrm{~m}^{-1} \mathrm{sr}^{-1}$ (corresponding to a visual range of the order of $30 \mathrm{~km}$ ). This is roughly one third of the values re-

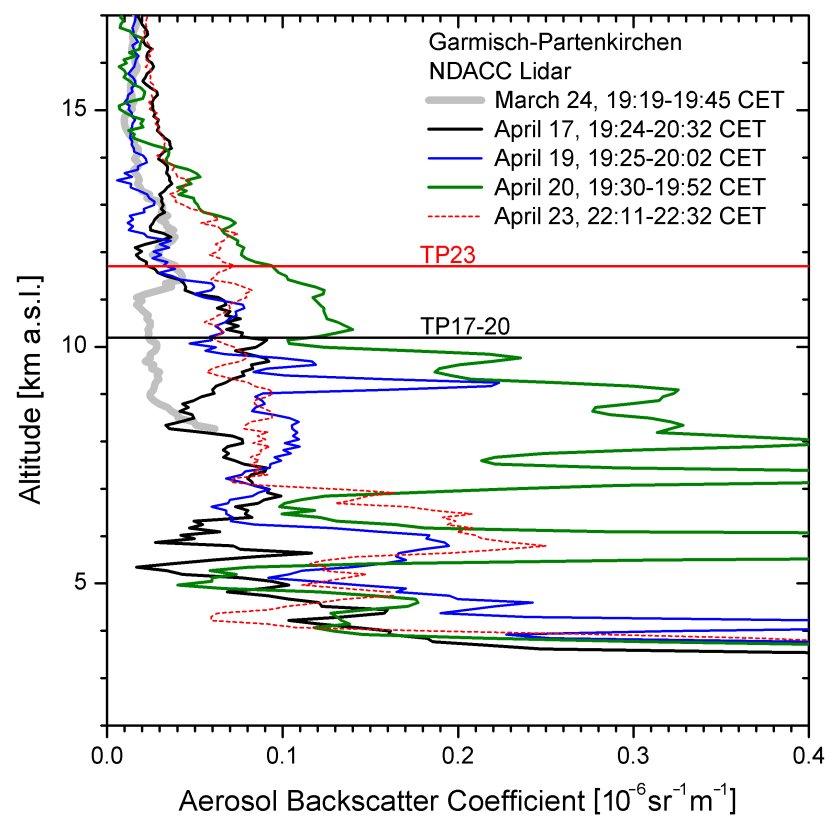

Fig. 9. Enlarged version of Fig. 8; the average Munich tropopause position for the period 17 to 20 April 2010 (TP17-20), and that of 23 April 2010, 19:00 CET (TP23), are given. The tropopause was $10.18 \mathrm{~km} \pm 0.35 \mathrm{~km}$ from 17 April to the middle of 21 April (Column 3 of Table 2). It then grew to almost $12 \mathrm{~km}$. For comparison, one profile from the pre-eruption phase is given (24 March, broad grey curve).

ported for Maisach and Leipzig and one fifth of the values reported for Hamburg (Ansmann et al., 2010), in qualitative agreement with the FLEXPART results in Fig. 7 that indicate less overlap of the plume with our site. The presence of the volcanic plume at about $3000 \mathrm{~m}$ on all four days is supported by the $\mathrm{SO}_{2}$ measurements at the Schneefernerhaus ( $2650 \mathrm{~m}$ a.s.l., less than $10 \mathrm{~km}$ away from IMK-IFU) by the German Weather Service (Flentje et al., 2010; Gilge and Plass-Dülmer, 2010).

In addition to the spike at about $3000 \mathrm{~m}$ (Fig. 8) we see aerosol structures weaker by one order of magnitude $\left(\beta_{\mathrm{P}} \approx(1-2) \times 10^{-7} \mathrm{~m}^{-1} \mathrm{sr}^{-1}\right.$, larger on 20 April) also in the free troposphere above $4 \mathrm{~km}$. The structures extend 2 to $4 \mathrm{~km}$ into the lower stratosphere. For comparison, the uncertainty of the profiles within the part of the stratosphere displayed in Fig. 9 is estimated as $5 \times 10^{-9} \mathrm{~m}^{-1} \mathrm{sr}^{-1}$.

The layering changed from day to day (Fig. 9). In addition, Fig. 10 documents a considerable short-term variability for 19 April, which indicates a rather fresh source and, thus, most likely the presence of volcanic ash from Iceland. The upper boundary of these aerosol layers was roughly $12 \mathrm{~km}$ on 17 and 19 April, and $14.3 \mathrm{~km}$ on 20 April (Fig. 9), i.e., above the thermal tropopause that was $10.2 \mathrm{~km}$ on average on these days. On 23 April the upper edge of the additional aerosol is most likely located at $13 \mathrm{~km}$, although some decrease of the 
Table 2. Tropopause altitude (TPA) and maximum relative humidity (MRH) between TPA-3 km and TPA for Keflavik (Iceland) and Munich (Germany) for the relevant periods in April 2010; in the presence of several temperature edges the one closest to the final drop in relative humidity was selected.

\begin{tabular}{|c|c|c|c|}
\hline Day & Time [UTC] & TPA $[\mathrm{km}]$ & $\mathrm{MRH}[\%]$ \\
\hline \multicolumn{4}{|c|}{ (a) Keflavik (Iceland) } \\
\hline \multirow[t]{2}{*}{13 April } & 00:00 & 11.1 & 47 \\
\hline & $12: 00$ & 11.4 & 60 \\
\hline \multirow[t]{2}{*}{14 April } & 00:00 & 10.2 & 40 \\
\hline & $12: 00$ & 8.9 & 38 \\
\hline \multirow[t]{2}{*}{15 April } & 00:00 & 9.4 & 76 \\
\hline & $12: 00$ & 9.9 & 69 \\
\hline \multirow[t]{2}{*}{16 April } & 00:00 & 9.5 & 79 \\
\hline & $12: 00$ & 7.4 & 37 \\
\hline \multirow[t]{2}{*}{17 April } & 00:00 & 6.9 & 23 \\
\hline & $12: 00$ & 9.4 & 33 \\
\hline \multirow[t]{2}{*}{18 April } & 00:00 & 10.7 & 57 \\
\hline & $12: 00$ & 9.9 & 85 \\
\hline \multicolumn{4}{|c|}{ (b) Munich (Germany) } \\
\hline \multirow[t]{2}{*}{17 April } & 00:00 & 9.8 & 36 \\
\hline & $12: 00$ & 10.1 & 40 \\
\hline \multirow[t]{2}{*}{18 April } & 00:00 & 10.3 & 32 \\
\hline & $12: 00$ & 9.6 & 63 \\
\hline \multirow[t]{4}{*}{19 April } & 00:00 & n.a. & n.a. \\
\hline & 06:00 & 10.0 & 42 \\
\hline & $12: 00$ & 10.3 & 47 \\
\hline & $18: 00$ & 10.1 & 52 \\
\hline \multirow[t]{4}{*}{20 April } & 00:00 & 10.7 & 45 \\
\hline & 06:00 & 10.3 & 39 \\
\hline & $12: 00$ & 10.4 & 26 \\
\hline & 18:00 & 10.1 & 59 \\
\hline 21 April & 00:00 & 10.1 & 66 \\
\hline \multirow[t]{2}{*}{23 April } & $12: 00$ & 11.8 & 69 \\
\hline & $18: 00$ & 11.7 & 60 \\
\hline 24 April & 00:00 & 11.6 & 72 \\
\hline
\end{tabular}

aerosol backscatter coefficient towards higher altitudes continues (see below).

The varying upper-tropospheric and lower-stratospheric contribution clearly differs from the weak broad background hump in the late period of the Sarychev phase. As one example for the stratospheric background during the period before the Eyjafjallajökull eruption, we add in Fig. 9 one curve for 24 March. The background layer typically ended between 24 and $26 \mathrm{~km}$ (not shown).

As described in more detail in Sect. 4.3, the air masses in the free troposphere and around the tropopause can be traced back to Iceland for 17 and 19 April. However, the interpretation changes for the other two days when other contributions, in particular Asian dust, could have influenced the tropopause region (see Sects. 4.3 and 4.4).
The lidar measurements on 19 April show cirrus-like (narrow) structures just below the tropopause (Fig. 10), within the aerosol hump between 7 and $12.3 \mathrm{~km}$. On the other hand the DIAL measurements revealed very dry conditions throughout the free troposphere and less than $50 \% \mathrm{RH}$ between 9 and $10 \mathrm{~km}$ (Fig. 11). The Munich radiosonde confirms the dry conditions (Table 2).

Due to the dryness an interpretation of the narrow spikes by cirrus clouds is difficult although clouds could be visually observed approaching from the south-west in the evening, indicating the arrival of the next storm. There are two possibilities. The first one is the presence of a thin ash layer from Iceland. The other one is related to the work by Seifert et al. (2011), who demonstrated the presence of ash-assisted formation of cirrus-like clouds during several days of the first observational period (see also other related papers cited in the introduction). Thus, it cannot be excluded that the spikes we observed below the tropopause during the second half of 19 April are related to the presence of ice-covered ash particles. Both possibilities yield a hint that a branch of the Eyjafjallajökull plume was present in the tropopause region on that day. The cirrus formation is likely to have occurred closer to the source where higher RH was registered. Between 14 and 16 April, the upper tropospheric RH over Iceland exceeded $80 \%$ several times (Table 2), i.e., it reached the range favourable for aerosol growth.

The free-tropospheric and lower-stratospheric backscatter coefficients for 20 April were clearly higher than those for the other days. However, this case is rather complex and, as will be shown in the following sections, is very likely related to aerosol from several different sources.

\subsection{HYSPLIT trajectories}

More than 350 HYSPLIT trajectory plots with at least three trajectories were generated for the period 15 to 23 April 2010. The trajectories were calculated both backward and forward in time because of the uncertainties due to sub-grid effects associated with the eruption or particle descent into other air masses. The HYSPLIT options of re-analysis meteorological input data and "model vertical velocity" were chosen. The backward trajectories were started above IMK-IFU in an altitude range from $1 \mathrm{~km}$ to $14 \mathrm{~km}$ a.s.l., the forward trajectories above Eyjafjallajökull mostly between 7 and $10 \mathrm{~km}$. Trajectories starting above a fixed single location (named "normal" in the HYSPLIT menu) were extended over 315 h. "Ensemble" trajectory plots display a trajectory bundle generated by varying the initial conditions by one horizontal and one vertical model grid unit around the starting point. These bundles cover some extended geographical range and, thus, give a more realistic picture of potential source or target regions. In our analysis, they frequently show horizontal overlap with the Eyjafjallajökull volcano (backward calculations) or Garmisch-Partenkirchen (forward calculations) even when single "normal" trajectories pass these locations 


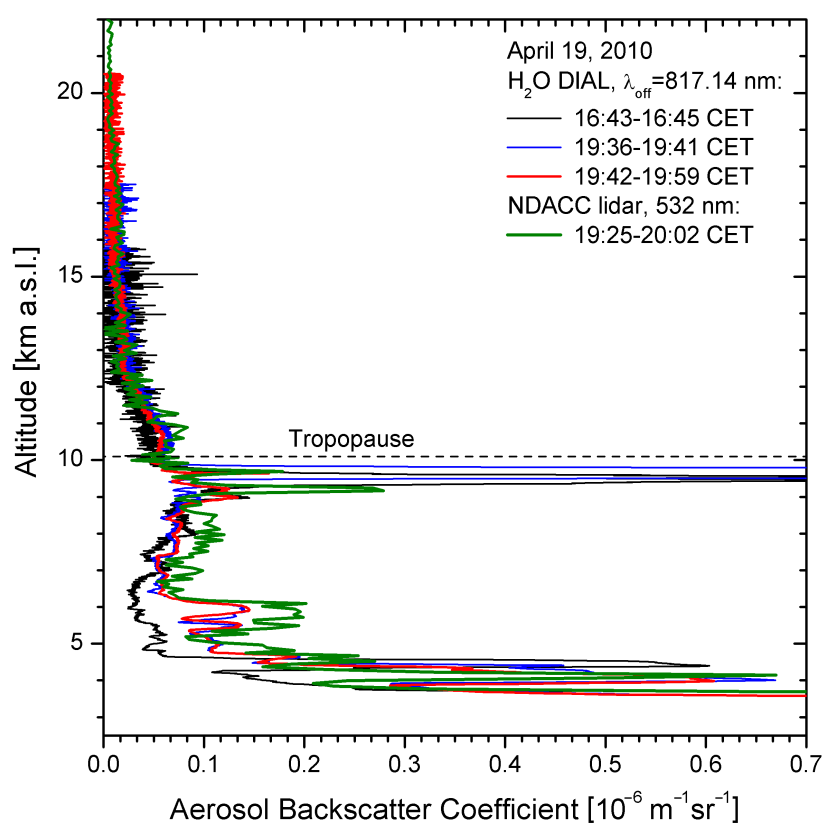

Fig. 10. The aerosol backscatter coefficients from the Zugspitze DIAL $(817 \mathrm{~nm})$ on 19 April 2010, together with the profile from the NDACC lidar $(532 \mathrm{~nm})$ for the same day.

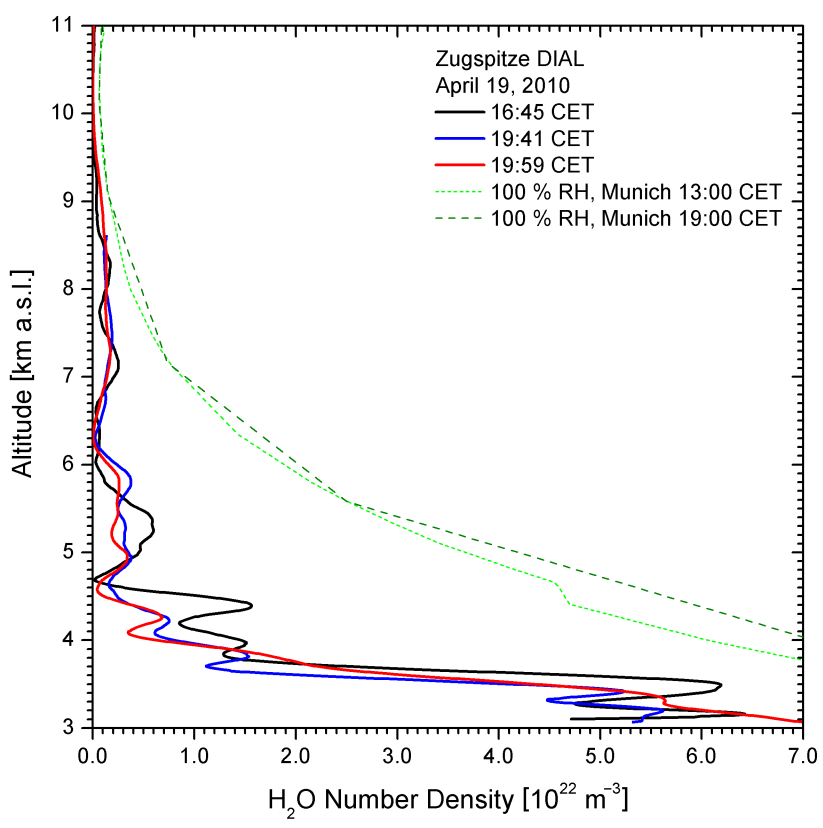

Fig. 11. Water-vapour profiles from the Zugspitze DIAL $(817 \mathrm{~nm})$ on 19 April 2010, obtained from the same measurements as those underlying Fig. 10. The times given are end times (see Fig. 10). The dashed curves give the $\mathrm{H}_{2} \mathrm{O}$ densities calculated from two radiosonde ascents at Oberschleißheim ("Munich" sonde) $100 \mathrm{~km}$ roughly to the north of IMK-IFU. The uncertainty level for the lidar measurements above $8 \mathrm{~km}$ is estimated as less than $5 \times 10^{-20} \mathrm{~m}^{-3}$. at some distance (see Fig. 12 as one example for 19 April). The ensemble trajectories are limited in time to $120 \mathrm{~h}$.

Around $3000 \mathrm{~m}$ the backward trajectories consistently show passage over Iceland for all four measurement times, in agreement with the presence of elevated $\mathrm{SO}_{2}$ mentioned above. The travel times grow from $2.5 \mathrm{~d}$ (17 April) to $4 \mathrm{~d}$ (19 April), and $8 \mathrm{~d}$ (20 and 23 April), consistent with a slowing of the air masses with the eastward propagation of the highpressure zone over the North Sea.

In the free troposphere and the lowermost stratosphere the backward trajectories also clearly reveal Iceland as the closest source region on 17 and 19 April. At lower altitudes the trajectories reveal subsidence towards Europe. Around the tropopause and at higher altitudes an almost horizontal flow was found (e.g., Fig. 12). Horizontal propagation is typical of this altitude range and prevents an upward transport of the aerosol farther into the stratosphere, most likely also in the case of fire plumes.

The analysis of the HYSPLIT co-ordinate file for Fig. 12 shows that ten of the 27 trajectories pass the volcano at distances corresponding to less than one degree in longitude and latitude. Four of these trajectories even meet the requirement of passing Eyjafjallajökull during the period of strong eruptions during the first half of 16 April and reaching at least $8.7 \mathrm{~km}$ (Arason et al., 2011). Three of them could be identified in Fig. 12 (see black circles) and are localized at about $9.6 \mathrm{~km}$ a.s.1. over Southern Iceland, which is the lowest altitude for this location within the ensemble.

The situation gradually changed after the first two measurement days. Other source regions began to matter. For the measurement on 20 April, just the aerosol peak between 5.5 and $7 \mathrm{~km}$ could be clearly traced back to Iceland by ensemble trajectories (not shown). The backward trajectories started above this altitude range mostly passed to the southwest of Iceland. However, for several start altitudes in the tropopause region (chosen at intervals of $50 \mathrm{~m}$ in this case) single trajectories of the respective bundles hit the Eyjafjallajökull position as seen in the example of Fig. 13. Thus, some volcanic contribution cannot be excluded in the lowermost stratosphere also on this day, although this is not the only source of aerosol (see further below).

To harden these findings a large number of forward ensemble plots were generated. These images (not shown) revealed a transition in the upper troposphere and lower stratosphere from the initial eastward propagation of the plume to a southward propagation. This transition occurred in the late morning of 17 April. The southward propagation agrees with the situation in Fig. 13. This behaviour continued until the end of our calculations at 04:00 CET on 18 April, which was determined by the end of the strong eruptions (Arason et al., 2011). An additional branch formed, first moving towards Greenland and then propagating to Europe. Trajectories from both branches pass in the vicinity of GarmischPartenkirchen, at a variety of altitudes and times on 20 and 


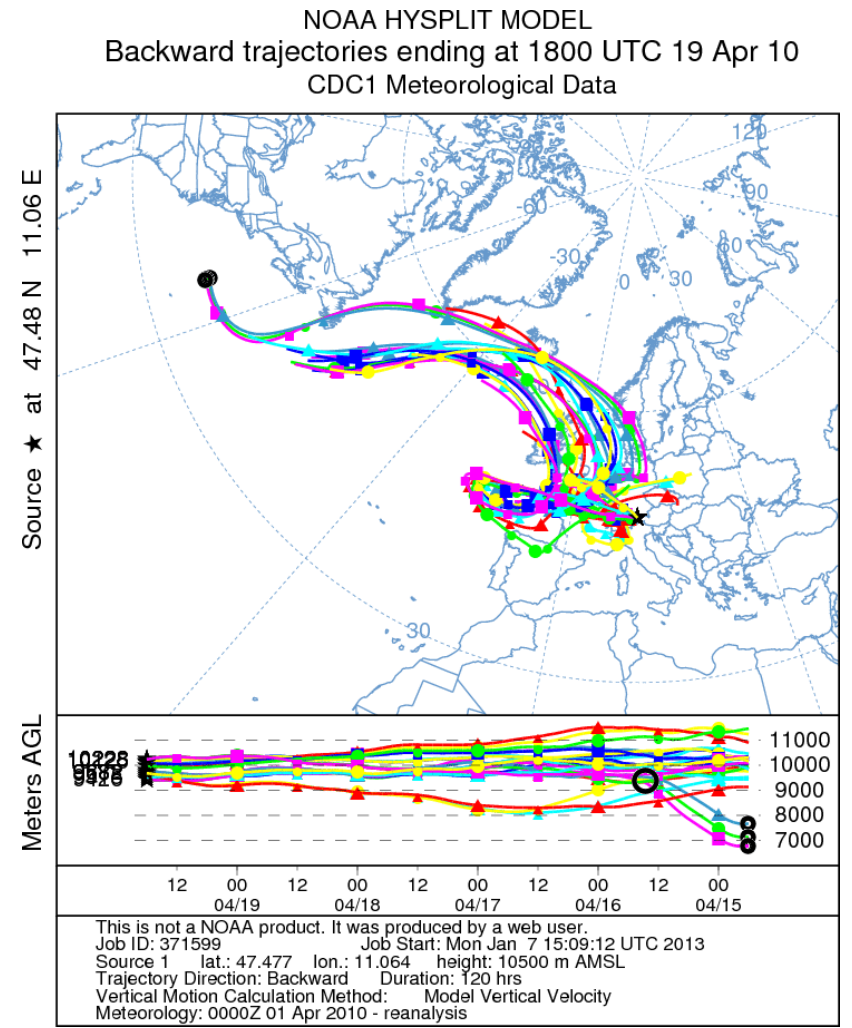

Fig. 12. HYSPLIT backward ensemble trajectories initiated at $10500 \mathrm{~m}$ a.s.l. over the position of IMK-IFU on 19 April at 19:00 CET (18:00 UTC); this plot is characteristic of the entire tropopause region for this start time. The position of GarmischPartenkirchen is marked by an asterisk. Please, note that the altitude in the second panel is given with respect to ground level (AGL), i.e., $730 \mathrm{~m}$ a.s.l at the lidar site. Most trajectories form an extra loop north of Spain that extends the travel time in comparison with 17 April. The three trajectories with the best overlap with a period of strong eruptions on 16 April are marked with black circles, the large circle showing their period and altitude of passage over Eyjafjallajökull.

21 April. Because of this complexity we do not describe the details of this analysis here.

For the early-night measurements on 20 April the backward normal and ensemble trajectories reveal advection from North America and beyond. In the ensemble trajectory plots initiated between 7 and $13 \mathrm{~km}$ a separate branch is indicated by a single trajectory (light blue) that ends over the area southwest of Hudson's Bay on 16 April, at lower altitudes (see label $\mathrm{G}$ in the example of Fig. 13). This branch becomes more pronounced for the trajectories initiated one hour later (at 19:00 UTC, not shown). It turns out to overlap with an Asian dust plume further discussed in Sect. 4.4.

On 23 April the situation was finally entirely different since no advection from Iceland is obtained for any altitude above $4 \mathrm{~km}$. For instance, for altitudes between 6 and $9 \mathrm{~km}$ a.s.l. above the lidar they lead back to the north-western part

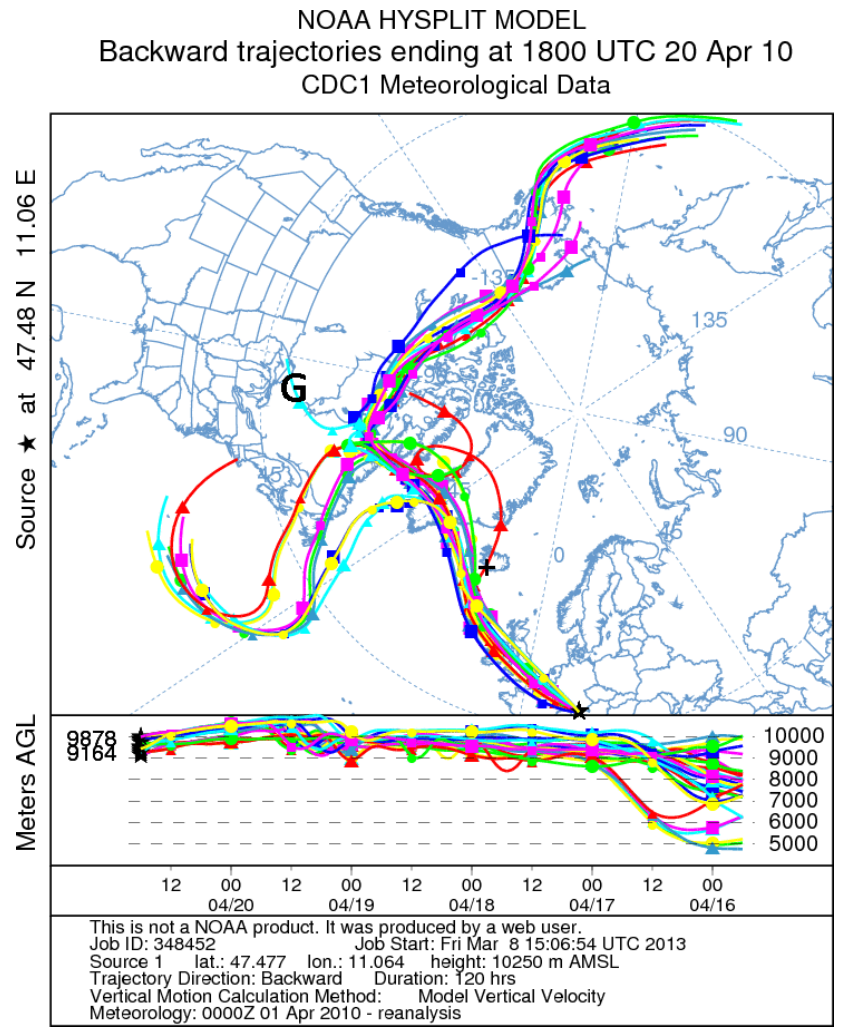

Fig. 13. HYSPLIT backward ensemble trajectories initiated at $10250 \mathrm{~m}$ a.s.l. over the position of IMK-IFU on 20 April at 19:00 CET; the position of Garmisch-Partenkirchen is marked by an asterisk, that of Eyjafjallajökull by a cross. G denotes the region where the evidence of Gobi dust in the OMI images ends.

of the Sahara where they propagate at altitudes below $3 \mathrm{~km}$. The observation of Saharan dust in the upper troposphere, though with low concentration, is rather special. Normally, upper boundaries of Saharan dust layers are found between 5 and 6 km (e.g., Jäger et al., 1988; Papayannis et al., 2008). Finally, the trajectories for 11 to $14 \mathrm{~km}$ stay at high altitudes and far south of Iceland. Some of them reach the East Asian deserts at low altitudes which, again, could suggest the presence of Asian dust.

\subsection{Satellite data}

Aerosol images from the CALIOP space-borne lidar onboard the CALIPSO satellite have been inspected for the period between 12 and 23 April. In contrast to the Sarychev aerosol (Sect. 3.4) the Eyjafjallajökull particles were strongly depolarizing, which is consistent with the lidar observations over Europe (Ansmann et al., 2011; Gasteiger et al., 2011; Groß et al., 2012).

The orbits were rarely sufficiently close to the volcano to allow us to derive a complete time series of the top altitude of the eruption. However, passes in the vicinity indicate that at least $9 \mathrm{~km}$ were reached in the initial phase. Some air mass 
rising up to $11 \mathrm{~km}$ on the travel towards Europe is indicated, but there is some uncertainty about this since cirrus clouds could co-exist.

To detect other dense aerosol plumes of potential importance, OMI (Ozone Monitoring Instrument, http://ozoneaq. gsfc.nasa.gov/OMIAerosol.md) aerosol images were inspected for several weeks preceding the Eyjafjallajökull eruption. One big plume was, indeed, found that emerged from the eastern part of the Gobi Desert on 8 April and could be traced forward by OMI images to the region southwest of Hudson's Bay where it arrived between 16 and 17 April. We verified this plume along this path by CALIOP images. The main portion stayed around $5 \mathrm{~km}$, but also uppertropospheric contributions were present up to roughly $8 \mathrm{~km}$. In combination with trajectory results in Sect. 4.3 (Fig. 13) we conclude that the aerosol layers between $7 \mathrm{~km}$ and $13 \mathrm{~km}$ are related to a dust storm in East Asia, with potential contributions from Iceland.

\subsection{The 2011 eruptions}

The new period of strong volcanic activity did not come to an end in 2011. Another two violent eruptions, those of Grimsvötn (Iceland, 21 May 2011), and Nabro (Eritrea, 12 June 2011) injected material into the stratosphere. There is consensus within the international lidar community that the pronounced rise in stratospheric aerosol in summer and autumn 2011, resulting in the characteristic violet sky after sunset, was due to the Nabro plume. This view was very recently confirmed by the results of Bourassa et al. (2012). Grimsvötn exploded spectacularly, and the ash was, indeed, observed over Scandinavia (Tesche et al., 2012). Because of presence of the Nabro aerosol we do not have any evidence of having detected aerosol from that plume above our site.

The Nabro plume reached an altitude of $13.7 \mathrm{~km}$ (Massie, 2012; Bourassa et al., 2012; Sawamura et al., 2012) and presumably contained record-setting amounts of $\mathrm{SO}_{2}$ (http: //en.wikipedia.org/wiki/2011_Nabro_eruption; references in Sawamura et al., 2012). The Nabro eruption is classified as VEI $=4$ in http://en.wikipedia.org/wiki/List_ of_large_volcanic_eruptions_in_the_21st_century. The plume first propagated north-westward where it was registered at Mediterranean EARLINET stations. Our first detection took place much later, on 19 July with the DIAL, and on 1 August with the NDACC lidar. As in the case of the Sarychev plume, first a spiky structure with pronounced intraday variability was observed up to $15 \mathrm{~km}$ (DIAL). In the second half of August, the aerosol settled into a broad hump peaking between 15 and $17 \mathrm{~km}$, with an upper end at about $19 \mathrm{~km}$. The hump phase was documented further by DIAL measurements, after a major system breakdown of the aerosol lidar.

In addition, Fig. 1 reveals some increase of the stratospheric aerosol in February and March 2011. The additional particles were confined to the lower part of the detection range. The clearly visible upper edge expanded from 16 to $20 \mathrm{~km}$ during that period. Some zonal flow around the Northern Hemisphere is indicated by $315 \mathrm{~h}$ backward trajectories. A potential source of this aerosol is the Shiveluch eruption, starting on 28 October 2010, that reached about $12 \mathrm{~km}$ (Table 1).

\section{Discussion and conclusions}

The long background period after the end of the Pinatubo phase and recent moderate eruptions yield insight into the impact of processes maintaining the stratospheric aerosol layer. Tropospheric air pollution of both natural and anthropogenic origin can yield a minor contribution. Deep pyroconvection, PSC formation and upward transport of mineral dust have been identified as aerosol sources occasionally yielding short-lived stratospheric contributions slightly exceeding the 1997-2006 background (Sects. 3.3, 4.3 and 4.4). Upward injection of tropospheric air into the stratosphere is most commonly achieved via deep convection or, at a level of several per cent, in the outflow of warm conveyor belts (WCBs; Stohl, 2001; Wernli and Bourqui, 2002; Sprenger and Wernli, 2003). The WCB mechanism should be more important for trace gases (Stohl and Trickl, 1999; Trickl et al., 2003) than for aerosols due to washout. However, it maximizes downwind of Asia and North America (Stohl, 2001), and, thus, small injections of polluted air from these continents into the stratosphere cannot be excluded. This mechanism should preferentially lead to a stratospheric impact at higher latitudes. Asian pollution could also be exported to the lowermost stratosphere by the monsoon circulation (e.g., Randel et al., 2010; Vernier et al., 2011a).

Given the limitations of our data, we cannot resolve a trend related to anthropogenic influence. The positive trend in stratospheric aerosol load observed over Mauna Loa (Hofmann et al., 2009), starting as early as in 1998, is not visible in our data, or is at least strongly delayed. As pointed out in Sect. 3.2 the latitudinal differences can to a major extent be interpreted by the differences in volcanic activity for the two latitudes. This view is hardened by Vernier et al. (2011b), who report on a tropical stratospheric aerosol layer related to volcanic eruptions, which has been detected in satellite measurements and which developed between 1997 and 2009. The particles from the individual bursts are subsequently transported to higher altitudes and latitudes by the BrewerDobson circulation. In addition to the reported strong direct injections into the tropical stratosphere, also some material from the frequent tropical eruptions just reaching the upper troposphere (Massie, 2012) could indirectly enter the stratosphere. Here, the pronounced vertical exchange in the vicinity of the subtropical jet stream must be taken into consideration (e.g., Sprenger et al., 2003; Trickl et al., 2011).

For our latitude, the tropical eruptions during the postPinatubo period only matter in the cases of Soufrière Hills and Nabro. The results in Fig. 1 mostly correlate with the 
magnitude of the mid-latitude eruptions, and a comparison with Table 1 and other sources confirms that a volcanic explosivity index of at least four and an eruption altitude several kilometres above the tropopause are required to influence significantly the level of stratospheric aerosol above our station (see Deshler, 2008).

The Soufrière Hills and Nabro cases suggest that transport of lower-stratospheric aerosol from the tropics to the midlatitudes is rather episodic and related to favourable meteorological patterns. In addition, a lifetime of less than one year was determined for these cases. Quite differently, after the considerably stronger and higher-reaching El Chichon and Pinatubo eruptions a steady growth of the aerosol load was observed above Garmisch-Partenkirchen during the first six months that was followed by a decay over several years. The decay pattern was modulated in phase with the quasi-biennial oscillation (Trepte and Hitchman, 1992; Jäger, 2005). This behaviour cannot be generalized: quite interestingly, a much faster decay within about one year was observed in the case of the mid-latitude eruption of Mt St Helens in 1980 that reached more than $24 \mathrm{~km}$. In the mid-latitudes one would expect faster removal from the stratosphere due to the downward motion of the Brewer-Dobson circulation and due to processes like tropopause folding (Holton et al., 1995; Stohl et al., 2003). In fact, we have observed aerosol in several deep stratospheric air intrusions into the troposphere during the phase of pronounced eruptions in 2009 (Trickl and Vogelmann, publication planned; see also Browell et al., 1987).

Even during the background period contributions from the frequent moderate eruptions (Table 1) cannot be excluded. For the mid-latitude volcanoes the tropopause is lower and eruptions can reach the tropopause region much easier. Martinsson et al. (2005) found a pronounced increase of sulphurcontaining particles above the tropopause for CARIBIC (Civil Aircraft for Regular Investigation of the Atmosphere Based on an Instrument Container) flights during the period 1999-2002, i.e., when the stratospheric background was the lowest. Unless there is a relevant contribution from air traffic in the flight corridors, this points to the presence of particles from volcanic eruptions. However, stratospheric contributions for eruption altitudes below $12 \mathrm{~km}$ (Table 1) must be very low since our data do not yield much more than shortterm structures just above the tropopause.

In this context the Eyjafjallajökull eruption was ideal for estimating the impact of bursts just reaching the tropopause region because of its proximity. We could verify pronounced contributions around $3 \mathrm{~km}$ on all four measurement days: 17 , 19, 20 and 23 April 2010. In the lower stratosphere our analysis yields clear evidence of advection of volcanic aerosol just on the first two measurement days. The backscatter coefficients within the first $2 \mathrm{~km}$ above the tropopause exceed the stratospheric background before the eruption by a factor of four to five. Some contribution from Iceland is possible also on the third day (20 April), but in this case it was very likely mixed with Asian dust. Our observations suggest that the volcanic particles did not proceed far into the stratosphere, not escaping the "mixing zone" around the thermal tropopause (e.g., Sprung and Zahn, 2010; Gettelman et al., 2011). Thus, due to dilution and the mentioned removal processes in the mid-latitudes there is little chance for a longterm stratospheric impact. Rising farther into the stratosphere would, e.g., require dynamical lifting or absorption of solar radiation by the particles (De Laat et al., 2012).

Several moderate eruptions also reaching altitudes around $10 \mathrm{~km}$ occurred in Kamchatka and on the Kuril Islands in late 2009 and early 2010. In contrast to the Redoubt case (2009; Fig. 5) the forward trajectories calculated for these eruptions do not reveal direct transport to Europe, the air masses obviously staying in regions around the volcanic sources for an extended period of time. Nevertheless, some crosstropopause hump structure, similar to that for the Icelandic eruption and probably originating from these eruptions, was observed in early 2010 and stimulates thoughts about a similar horizontal propagation in the tropopause region. This structure strongly diminished until the middle of March as visible in the reference trace in Fig. 9, confirming the idea about short dwell times of lower-stratospheric aerosol in the mid-latitudes.

Acknowledgements. The authors thank W. Seiler, H. P. Schmid, and the late R. Reiter for their support along this long measurements series. They acknowledge the important role of W. Carnuth for the lidar work at IFU, who was responsible for the first version of the big aerosol lidar and other lidar systems. P. Keckhut provided temperature calculations with the MIMOSA model for the December-2006 episode, and M. Sprenger the daily forecast of stratospheric air intrusions. N. Kristiansen and S. Eckhardt made available the FLEXPART model run. This work was funded by numerous funding agencies during the past fifteen years by the German Federal Ministry of Education and Research within the German Lidar Network and the European Union within the European Aerosol Research Lidar Network (EARLINET) and EARLINET-ASOS, and has contributed to the Network of Atmospheric Composition Change (NDACC).

The service charges for this open access publication have been covered by a Research Centre of the Helmholtz Association.

Edited by: G. Pappalardo

\section{References}

Ansmann, A., Tesche, M., Groß, S., Freudenthaler, V., Seifert, P., Hiebsch, A., Schmidt, J., Mattis, I., Wandinger, U., Mattis, I., Müller, D., and Wiegner, M.: The 16 April 2010 major volcanic ash plume over central Europe: EARLINET lidar and AERONET photometer observations at Leipzig and Munich, Germany, Geophys. Res. Lett., 37, L13810, doi:10.1029/2010GL043809, 2010. 
Ansmann, A., Tesche, M., Seifert, P., Groß, S., Freudenthaler, V., Apituley, A., Wilson, K. M., Serikov, I., Linné, H., Heinold, B., Hiebsch, A., Schnell, F., Schmidt, J., Mattis, I., Wandinger, U., and Wiegner, M.: Ash and fine-mode particle mass profiles from EARLINET-AERONET observations over central Europe after the eruptions of the Eyjafjallajökull volcano in 2010, J. Geophys. Res., 116, D00U02, doi:10.1029/2010JD015567, 2011.

Arason, P., Petersen, G. N., and Bjornsson, H.: Observations of the altitude of the volcanic plume during the eruption of Eyjafjallajökull, April-May 2010, Earth Syst. Sci. Data, 3, 9-17, doi:10.5194/essd-3-9-2011, 2011.

Bates, D. R.: Rayleigh Scattering by Air, Planet. Space. Sci., 32, 785-790, 1984.

Berresheim, H. and Jaeschke, W.: The Contribution of Volcanoes to the Global Atmospheric Sulfur Budget, J. Geophys. Res., 88, 3732-3740, 1983.

Bigg, E. K.: The Detection of Atmospheric Dust and Temperature Inversions by Twilight Scattering, J. Meteorol., 13, 262-268, 1956.

Bingemer, H., Klein, H., Ebert, M., Haunold, W., Bundke, U., Herrmann, T., Kandler, K., Müller-Ebert, D., Weinbruch, S., Judt, A., Wéber, A., Nillius, B., Ardon-Dryer, K., Levin, Z., and Curtius, J.: Atmospheric ice nuclei in the Eyjafjallajökull volcanic ash plume, Atmos. Chem. Phys., 12, 857-867, doi:10.5194/acp12-857-2012, 2012.

Bösenberg, J., Alpers, M., Althausen, D., Ansmann, A., Böckmann, C., Eixmann, R., Franke, A., Freudenthaler, V., Giehl, H., Jäger, H., Kreipl, S., Linné, H., Matthias, V., Mattis, I., Müller, D., Sarközi, J., Schneidenbach, L., Schneider, J., Trickl, T., Vorobieva, E., Wandinger, U., and Wiegner, M.: The German Aerosol Lidar Network: Methodology, Data, Analysis, MaxPlanck-Institut für Meteorologie (Hamburg, Germany), Report Nr. 317, ISSN 0937-1060, 155 pp., 2001.

Bösenberg, J., Matthias, V., Amodeo, A., Amoiridis, V., Ansmann, A., Baldasano, J. M., Balin, I., Balis, D., Böckmann, C., Boselli, A., Carlsson, G., Chaikovski, A., Chourdakis, G., Comerón, A., De Tomasi, F., Eixmann, R., Freudenthaler, V., Giehl, H., Grigorov, I., Hågård, A., Iarlore, M., Kirsche, A., Kolarov, G., Komguem, L., Kreipl, S., Kumpf, W., Larchevêque, G., Linné, H., Matthey, R., Mattis, I., Mekler, A., Mironova, I., Mitev, V., Mona, L., Müller, D., Music. S., Nickovic, S., Pandolfi, M., Papayannis, A., Pappalardo, G., Pelon, J., Pérez, C., Perrone, R. M., Persson, R., Resendes, D. P., Rizi, V., Rocadenbosch, F., Rodrigues, J. A., Sauvage, L., Schneidenbach, L., Schumacher, R., Sherbakov, V., Simeonov, V., Sobolewski, P., Spinelli, N., Stachlewska, I., Stoyanov, D., Trickl, T., Tsaknakis, G., Vaughan, G., Wandinger, U., Wang, X., Wiegner, M., Zavrtanik, M., and Zerefos, C.: EARLINET: A European Aerosol Research Lidar Network to Establish an Aerosol Climatology, J. Bösenberg, Coordinator, Max-Planck-Institut für Meteorologie (Hamburg, Germany), Report Nr. 348, ISSN 0937 1060, 155 pp., 2003.

Bourassa, A. E., Degenstein, D. A., Elash, B. J., and Llewellyn, E. J.: Evolution of the stratospheric aerosol enhancement following the eruptions of Okmok and Kasatochi: OdinOSIRIS measurements, J. Geophys. Res., 115, D00L03, doi:10.1029/2009JD013274, 2010.

Bourassa, A. E., Robock, A., Randel, W. J., Deshler, T., Rieger, L. A., Lloyd, N. D., Llewellyn, E. J., and Degenstein, D. A.: Large Volcanic Aerosol Load in the Stratosphere Linked to Asian Mon- soon Transport, Science, 337, 78-81 (and supporting online material), 2012.

Brion, J., Chakir, A., Charbonnier, J., Daumont, D., Parisse, C., and Malicet, J.: Absorption Spectra Measurements for the Ozone Molecule in the 350-830 nm Region, J. Atmos. Chem., 30, $291-$ 299, 1998.

Browell, E. V., Danielsen, E. F., Ismail, S., Gregory, G. L., and Beck, S. M.: Tropopause Fold Structure Determined from Airborne Lidar and in Situ Measurements, J. Geophys. Res., 92, 2112-2120, 1987.

Campbell, J. R., Welton, E. J., Krotkov, N. A., Yang, K., Stewart, S. A., and Fromm, M. D.: Liekely seeing of cirrus clouds by stratospheric Kasatochi volcanic aerosol particles near a mid-latitude tropopause fold, Atmos. Environ., 446, 441-448, 2012.

Charlson, R. J., Langner, J., Rodhe, H., Leovy, C. B., and Warren, S. G.: Perturbation of the northern hemisphere radiative balance by backscattering from anthropogenic sulfate aerosols, Tellus B, 43, 152-163, 1991.

Carnuth, W. and Trickl, T.: Transport studies with the IFU threewavelength aerosol lidar during the VOTALP Mesolcina experiment, Atmos. Environ., 34, 1425-1434, 2000.

Carnuth, W., Kempfer, U., and Trickl, T.: Highlights of the Tropospheric Lidar Studies at IFU within the TOR Project, Tellus B, 54, 163-185, 2002.

Dacre, H. F., Grant, A. L. M., Hogan, R. J., Belcher, S. E., Thomson, D. J., Devenish, B, J., Marenco, F., Hort, M. C., Haywood, J. M., Ansmann, A., Mattis, I., and Clarisse, L.: Evaluating the structure and magnitude of the ash plume during the initial phase of the 2010 Eyjafjallajökull eruption using lidar observations and NAME simulations, J. Geophys. Res., 116, D00U03, doi:10.1029/2011JD015608, 2011.

De Laat, A. T. J., Stein Zweers, D. C., Boers, R., and Tuinder, O. N. E.: A solar escalator: Observational evidence of the self-lifting of smoke and aerosols by absorption of solar radiation in the February 2009 Australian Black Saturday plume, J. Geophys. Res., 117, D04204, doi:10.1029/2011JD017016, 2012.

Deshler, T.: A review of global stratospheric aerosol: Measurements, importance, life cycle, and stratospheric aerosol, Atmos. Res., 90, 223-232, 2008

Deshler, T., Anderson-Sprecher, R., Jäger, H., Barnes, J., Hofmann, D. J., Clemensha, B., Simonich, D., Grainger, R. G., and GodinBeekmann, S.: Trends in the non-volcanic component of stratospheric aerosol over the period 1971-2004, J. Geophys. Res., 111, D01201, doi:10.1029/2005JD006089, 2006.

Draxler, R. and Hess, G.: An overview of the HYSPLIT_4 modelling system for trajectories, dispersion, and deposition, Aust. Meteorol. Mag., 47, 295-308, 1998.

Eisele, H., Scheel, H. E., Sladkovic, R., and Trickl, T.: Highresolution Lidar Measurements of Stratosphere-troposphere Exchange, J. Atmos. Sci., 56, 319-330, 1999.

Emeis, S., Forkel, R., Junkermann, W., Schäfer, K., Flentje, H., Gilge, S., Fricke, W., Wiegner, M., Freudenthaler, V., Groß, S., Ries, L., Meinhardt, F., Birmili, W., Münkel, C., Obleitner, F., and Suppan, P.: Measurement and simulation of the 16/17 April 2010 Eyjafjallajökull volcanic ash layer dispersion in the northern Alpine region, Atmos. Chem. Phys., 11, 2689-2701, doi:10.5194/acp-11-2689-2011, 2011.

Fernald, F. G.: Analysis of atmospheric lidar observations: some comments, Appl. Opt., 23, 652-653, 1984. 
Fiocco, G. and Grams, G: Observations of the Aerosol Layer at 20 km by Optical Radar, J. Atmos. Sci., 21, 323-324, 1964.

Flentje, H., Claude, H., Elste, T., Gilge, S., Köhler, U., PlassDülmer, C., Steinbrecht, W., Thomas, W., Werner, A., and Fricke, W.: The Eyjafjallajökull eruption in April 2010 - detection of volcanic plume using in-situ measurements, ozone sondes and lidar-ceilometer profiles, Atmos. Chem. Phys., 10, 10085-10092, doi:10.5194/acp-10-10085-2010, 2010.

Forster, C., Wandinger, U., Wotawa, G., James, P., Mattis, I., Althausen, D., Simmonds, P., O'Doherty, S., Jennings, S. G., Kleefeld, C., Schneider, J., Trickl, T., Kreipl, S., Jäger, H., and Stohl, A.: Transport of boreal forest fire emissions from Canada to Europe, J. Geophys. Res., 106, 22887-22906, 2001.

Freudenthaler V.: Lidarmessungen der räumlichen Ausbreitung sowie mikrophysikalischer und optischer Parameter von Flugzeugkondesstreifen, Dissertation, Universität Hohenheim, Germany (1999) und Schriftenreihe des Fraunhofer-Instituts für Atmosphärische Umweltforschung, Vol. 63, 134 pp., Shaker Verlag GmbH, Aachen, ISBN 3-8265-6973-3, ISSN 1436-1094, 2000 (in German).

Freudenthaler, V., Homburg, F., and Jäger, H.: Ground-based mobile scanning LIDAR for remote sensing of contrails, Ann. Geophys., 12, 956-961, doi:10.1007/s00585-994-0956-9, 1994.

Freudenthaler, V., Homburg, F., and Jäger, H.: Contrail observations by ground-based mobile scanning lidar: cross-sectional growth, Geophys. Res. Lett., 22, 3501-3504, 1995.

Fromm, M. and Servranckx, R.: Transport of forest fire smoke, above the tropopause, supercell convection, Geophys. Res. Lett., 30, 1542, doi:10.1029/2002GL016820, 2003.

Fromm, M., Alfred, J., Hoppel, K., Hornstein, J., Bevilacqua, R., Shettle, E., Servranckx, R., Li, Z., and Stocks, B.: Observations of boreal forest fire smoke in the stratosphere by POAM III, SAGE II, and lidar in 1998, Geophys. Res. Lett., 27, 1407-1410, 2000.

Fromm, M., Torres, O., Diner, D., Lindsey, D., Vant Hull, B., Servranckx, R., Shettle, E. P., and Li, Z.: Stratospheric impact of the Chisholm pyrocumulonimbus eruption: 1. Earthviewing satellite perspective, J. Geophys. Res., 113, D08202, doi:10.1029/2007JD009153, 2008a.

Fromm, M., Shettle, E. P., Fricke, K. H., Ritter, C., Trickl, T., Giehl, H., Gerding, M., Barnes, J., O’Neill, M., Massie, S. T., Blum, U., McDermid, I. S., Leblanc, T., and Deshler, T.: The stratospheric impact of the Chisholm PyroCumulonimbus eruption: 2. Vertical profile perspective, J. Geophys. Res., 113, D08203, doi:10.1029/2007JD009147, 2008b.

Fromm, M., Lindsey, D. T., Servranckx, R., Yue, G., Trickl, T., Sica, R., Doucet, P., and Godin-Beekmann, S.: The Untold Story of Pyrocumulonimbus, B. Am. Meterol. Soc., 91, 1193-1209, 2010.

Gasteiger, J., Groß, S., Freudenthaler, V., and Wiegner, M.: Volcanic ash from Iceland over Munich: mass concentration retrieved from ground-based remote sensing measurements, Atmos. Chem. Phys., 11, 2209-2223, doi:10.5194/acp-11-22092011, 2011.

Gettelman, A., Hoor, P., Pan, L. L., Randel, W. L., Hegglin, M. I., and Birner, T.: The Extratropical Upper Troposphere and Lower Stratosphere, Rev. Geophys 49, RG3003, doi:10.1029/2001RG000355, 2011.

Gilge, S. and Plass-Dülmer, C.: Stark erhöhte $\mathrm{SO}_{2}$-Konzentrationen an der Zugspitze infolge des Eyjafjallajökull-Ausbruchs, GAW-
Brief des DWD, 51, 2 pp., available at: http://www.dwd.de/gaw, 2010.

Grams, G. and Fiocco, G.: Stratospheric Aerosol Layer during 1964 and 1965, J. Geophys. Res., 72, 3523-3542, 1967.

Groß, S., Freudenthaler, V., Wiegner, M., Gasteiger, J., Geiß, A., and Schnell, F.: Dual-wavelength depolarization ratio of volcanic aerosols: Lidar measurements of the Eyjafjallajökull plume over Maisach, Germany, Atmos. Environ., 48, 85-96, 2012.

Hansen, J., Sato, M., Lacis, A., and Ruedy, R.: The missing climate forcing, Philos. Trans. R. Soc. B, 352, 231-240, 1997.

Hervig, M.: Stratospheric clouds over England, Geophys. Res. Lett., 26, 1137-1140, 1999.

Heue, K.-P., Brenninkmeijer, C. A. M., Wagner, T., Mies, K., Dix, B., Frieß, U., Martinsson, B. G., Slemr, F., and van Velthoven, P. F. J.: Observations of the 2008 Kasatochi volcanic $\mathrm{SO}_{2}$ plume by CARIBIC aircraft DOAS and the GOME-2 satellite, Atmos. Chem. Phys., 10, 4699-4713, doi:10.5194/acp-10-4699-2010, 2010.

Hofmann, D. J., Rosen, J. M., Pepin, T. J., and Pinnick, R. G.: Stratospheric Aerosol Measurements I: Time Variations at Northern Midlatitudes, J. Atmos. Sci., 32, 1446-1456, 1975.

Hofmann, D., Barnes, J., O’Neill, M., Trudeau, M., and Neely, R.: Increase in background stratospheric aerosol observed with lidar at Mauna Loa Observatory and Boulder, Colorado, Geophys. Res. Lett., 36, L15808, doi:10.1029/2009GL039008, 2009.

Holton, J. R., Haynes, P. H., McIntyre, M. E., Douglass, A. R., Rood, R. B., and Pfister, L.: Stratosphere-Troposphere Exchange, Rev. Geophys., 33, 403-439, 1995.

Hoyle, C. R., Pinti, V., Welti, A., Zobrist, B., Marcolli, C., Luo, B., Höskuldsson, Á., Mattsson, H. B., Stetzer, O., Thorsteinsson, T., Larsen, G., and Peter, T.: Ice nucleation properties of volcanic ash from Eyjafjallajökull, Atmos. Chem. Phys., 11, 9911-9926, doi:10.5194/acp-11-9911-2011, 2011.

Jäger, H.: Long-term record of lidar observations of the stratospheric aerosol layer at Garmisch-Partenkirchen, J. Geophys. Res., 110, D08106, doi:10.1029/2004JD005506, 2005.

Jäger, H. and Deshler, T.: Lidar backscatter to extinction, mass and area conversions for stratospheric aerosols based on midlatitude balloonborne size distribution measurements, Geophys. Res. Lett., 29, 1929, doi:10.1029/2002GL015609, 2002.

Jäger, H. and Deshler, T.: Correction to "Lidar backscatter to extinction, mass and area conversions for stratospheric aerosols based on midlatitude balloonborne size distribution measurements", Geophys. Res. Lett., 30, 1382, doi:10.1029/2003GL017189, 2003.

Jäger, H. and Wege, K.: Stratospheric Ozone Depletion at Northern Midlatitudes after Major Volcanic Eruptions, J. Atmos. Chem., 10, 273-287, 1990.

Jäger, H., Carnuth, W., and Georgi, B.: Observations of Saharan Dust at a North Alpine Station, J. Aerosol Sci., 19, 1235-1238, 1988.

Jäger, H., James, P., Stohl, A., and Trickl, T.: Long-Range Transport of Free-Tropospheric Aerosol: A Nine-year Climatology, pp. 795 to 796 in: Reviewed and Revised Papers Presented at the 23rd International Laser Radar Conference, Nara (Japan), 24 to 28 July 2006, edited by: Nagasawa, C. and Sugimoto, N., Tokyo Metropolitan University, Tokyo, Japan, ISBN 4-9902916$0-3,2006$. 
Junge, C. E. and Manson, J. E.: Stratospheric aerosol studies, J. Geophys. Res., 66, 2163-2182, 1961.

Keckhut, P., David, Ch., Marchand, M., Bekki, S., Jumelet, J., Hauchecorne, A., and Höpfner, M.: Observation of Polar Stratospheric Clouds down to the Mediterranean coast, Atmos. Chem. Phys., 7, 5275-5281, doi:10.5194/acp-7-5275-2007, 2007.

Klett, J. D.: Lidar inversion with variable backscatter/extinction ratios, Appl. Opt., 24, 1638-1643, 1985.

Kravits, B., Robock, A., Bourasa, A., Deshler, T., Wu, D., Mattis, I., Finger, F., Hoffmann, A., Ritter, C., Bitar, L., Duck, T., and Barnes, J. E.: Simulation and observations of stratospheric aerosols from the 2009 Sarychev volcanic eruption, J. Geophys. Res., 116, D18211, doi:10.1029/2010JD015501, 2011.

Martinsson, B. G., Nguyen, H. N., Brenninkmeijer, C. A. M., Zahn, A., Heintzenberg J., Hermann, M., and van Velthoven, P. F. J.: Characteristics and origin of lowermost stratospheric aerosol at northern midlatitudes under volcanically quiescent conditions based on CARIBIC observations, J. Geophys. Res., 110, D12201, doi:10.1029/2004JD005644, 2005.

Martinsson, B. G., Brenninkmeijer, C. A. M., Carn, S. A., Hermann, M., Heue, K.-P., van Velthoven, P. F. J., and Zahn, A.: Influence of the 2008 Kasatochi volcanic eruption on sulfurous and carbonaceous aerosol constituents in the lower stratosphere, Geophys. Res. Lett., 36, L12813, doi:10.1029/2009GL038735, 2009.

Massie, S. T.: Summary of volcanic activity, AURA Cloud/Aerosol/ $/ \mathrm{SO}_{2}$ Working Group, available via http://avdc.gsfc.nasa.gov/, release April 2012. The data have been mostly extracted from Smithsonian/USGS Weekly Volcanic Activity Report, http://volcano.si.edu/reports/usgs/index.cfm, 2012.

Mattis, I., Ansmann, A., Müller, D., Wandinger, U., and Althausen, D.: Multiyear aerosol observations with dual-wavelength Raman lidar in the framework of EARLINET, J. Geophys. Res., 109, D13203, doi:10.1029/2004JD004600, 2004.

Mattis, I., Seifert, P., Müller, D., Tesche, M., Hiebsch, A., Kanitz, T., Schmidt, J., Finger, F., Wandinger, U., and Ansmann, A.: Volcanic aerosol layers observed with multiwavelength Raman lidar over central Europe in 2008-2009, J. Geophys. Res., 115, D00L04, doi:10.1029/2009JD013472, 2010.

McCormick, M. P., Chu, W. P., Grams, G. W., Hamill, P., Herman, B. M., McMaster, L. R., Pepin, T. J., Russell, P. B., Steele, H. M., and Swissler, T. J.: High-Latitude Stratospheric Aerosols Measured by the SAM II Satellite System in 1978 and 1979, Science 214, 328-331, 1981.

Mona, L., Amodeo, A., D’Amico, G., Giunta, A., Madonna, F., and Pappalardo, G.: Multi-wavelength Raman lidar observations of the Eyjafjallajökull volcanic cloud over Potenza, southern Italy, Atmos. Chem. Phys., 12, 2229-2244, doi:10.5194/acp-12-22292012, 2012.

Nakada, E.: Special issue: The 2000 eruption of Miyakejima volcano, Japan, Edited by Setsuya Nakada and Tim Druitt, Bull. Volcanol., 67, 203-204, 2005.

Newhall, C. G. and Self, S.: The volcanic explosivity index (VEI): an estimate of explosive magnitude for historical volcanism, J. Geophys. Res., 87, 1231-1238, 1982.

Owens, J. C.: Optical Refractive Index of Air: Dependence on Pressure, Temperature and Composition, Appl. Optics, 6, 51-60, 1967.
Pan, L. L., M., Randel, W. J., Gary, B. L., Mahoney, M. J., and Hintsa, E. J.: Definitions and sharpness of the extratropical tropopause: A trace gas perspective, J. Geophys. Res., 109, D23103, doi:10.1029/2004JD004982, 2004.

Papayannis, A., Amiridis, V., Mona, L., Tsaknakis, G., Balis, D., Bösenberg, J., Chaikovski, A. De Tomasi, F., Grigorov, I., Mattis, I., Mitev, V., Müller, D., Nickovic, S., Pérez, C., Pietruczuk, A., Pisani, G., Ravetta, F., Rizi, V., Sicard, M., Trickl, T., Wiegner, M., Gerding, M., Mamouri, R. E., D’Amico, G., and Pappalardo, G.: Systematic lidar observations of Saharan dust over Europe in the frame of EARLINET (2000-2002), J. Geophys. Res., 113, D10204; doi:10.1029/2007JD009028, 2008.

Pappalardo, G., Mona, L., D’Amico, G., Wandinger, U., Adam, M., Amodeo, A., Ansmann, A., Apituley, A., Alados Arboledas, L., Balis, D., Boselli, A., Bravo-Aranda, J. A., Chaikovsky, A., Comeron, A., Cuesta, J., De Tomasi, F., Freudenthaler, V., Gausa, M., Giannakaki, E., Giehl, H., Giunta, A., Grigorov, I., Groß, S., Haeffelin, M., Hiebsch, A., Iarlori, M., Lange, D., Linné, H., Madonna, F., Mattis, I., Mamouri, R.-E., McAuliffe, M. A. P., Mitev, V., Molero, F., Navas-Guzman, F., Nicolae, D., Papayannis, A., Perrone, M. R., Pietras, C., Pietruczuk, A., Pisani, G., Preißler, J., Pujadas, M., Rizi, V., Ruth, A. A., Schmidt, J., Schnell, F., Seifert, P., Serikov, I., Sicard, M., Simeonov, V., Spinelli, N., Stebel, K., Tesche, M., Trickl, T., Wang, X., Wagner, F., Wiegner, M., and Wilson, K. M.: Four-dimensional distribution of the 2010 Eyjafjallajökull volcanic cloud over Europe observed by EARLINET, Atmos. Chem. Phys., 13, 4429-4450, doi:10.5194/acp-13-4429-2013, 2013.

Petersen, G. N.: A short meteorological overview of the Eyjafjallajökull eruption 14 April-23 May 2010, Weather, 65, 203-207, 2010.

Pittock, A. B.: Possible destruction of ozone by volcanic material at 50 mbar, Nature, 207, 182, 1965.

Prata, A. J., Carn, S. A., Stohl, A., and Kerkmann, J.: Long range transport and fate of a stratospheric volcanic cloud from Soufrière Hills volcano, Montserrat, Atmos. Chem. Phys., 7, 5093-5103, doi:10.5194/acp-7-5093-2007, 2007.

Randel, W. J., Pak, M., Emmons, L., Kinnison, D., Bernath, P., Walker, K. A., Boone, C., and Pumphrey, H.: Asian Monsoon Transport of Pollution to the Stratosphere, Science, 328, 611613, 2010.

Rauthe-Schöch, A., Weigelt, A., Hermann, M., Martinsson, B. G., Baker, A. K., Heue, K.-P., Brenninkmeijer, C. A. M., Zahn, A., Scharffe, D., Eckhardt, S., Stohl, A., and van Velthoven, P. F. J.: CARIBIC aircraft measurements of Eyjafjallajökull volcanic clouds in April/May 2010, Atmos. Chem. Phys., 12, 879-902, doi:10.5194/acp-12-879-2012, 2012.

Reichardt, J. and Reichardt, S.: Determination of cloud effective particle size from the multiple-scattering effect on lidar integration-method temperature measurements, Appl. Opt., 45, 2796-2804, 2006.

Reiter, R. and Carnuth, W.: Comparing Lidar Reflectivity Profiles Against Measured Profiles of Vertical Aerosol Distribution between 1 and 3 km a.s.1., Arch. Met. Geophys. Biokl. A 24, 69-92, 1975 .

Reiter, R., Jäger, H., Carnuth, W., and Funk, W.: The Stratospheric Aerosol Layer Observed by Lidar Since October 1976. A Contribution to the Problem of Hemispheric Climate, Arch. Met. Geophys. Biokl. B, 27, 121-149, 1979. 
Robock, A.: Volcanic eruptions and climate, Rev. Geophys., 38, 191-219, 2000.

Sawamura., P., Vernier, J. P., Barnes, J. E., Berkoff, T. A., Welton, E. J., Alados-Arboledas, L., Navas-Guzmán, F., Pappalardo, G., Mona, L., Madonna, F., Lange, D., Sicard, M., GodinBeekmann, S., Payen, G., Wang, Z., Hu, S., Tripathi, S. N., Cordoba-Jabonero, C., and Hoff, R. M.: Stratospheric AOD after the 2011 eruption of Nabro volcano measured by lidars over the Northern Hemisphere, Environ. Res. Lett., 7, 034013, doi:10.1088/1748-9326/7/3/034013, 2012.

Schumann, U., Weinzierl, B., Reitebuch, O., Schlager, H., Minikin, A., Forster, C., Baumann, R., Sailer, T., Graf, K., Mannstein, H., Voigt, C., Rahm, S., Simmet, R., Scheibe, M., Lichtenstern, M., Stock, P., Rüba, H., Schäuble, D., Tafferner, A., Rautenhaus, M., Gerz, T., Ziereis, H., Krautstrunk, M., Mallaun, C., Gayet, J.F., Lieke, K., Kandler, K., Ebert, M., Weinbruch, S., Stohl, A., Gasteiger, J., Groß, S., Freudenthaler, V., Wiegner, M., Ansmann, A., Tesche, M., Olafsson, H., and Sturm, K.: Airborne observations of the Eyjafjalla volcano ash cloud over Europe during air space closure in April and May 2010, Atmos. Chem. Phys., 11, 2245-2279, doi:10.5194/acp-11-2245-2011, 2011.

Seifert, P., Ansmann, A., Groß, S., Freudenthaler, V., Heinold, B., Hiebsch, A., Mattis, I., Schmidt, J., Schnell, F., Tesche, M., Wandinger, U., and Wiegner, M.: Ice formation in ashinfluenced clouds after the eruption, of the Eyjafjallajökull volcano in April 2010, J. Geophys. Res., 116, D00U04, doi:10.1029/2011JD015702, 2011.

Siebert, L., Simkin, T., and Kimberly, P.: Volcanoes of the world, Third Edition, Smithsonian Institution (Washington, D.C., U.S.A.), University of California Press (Berkeley, Los Angeles, London), ISBN 978-0-520-26877-7, 551 pp., 2010.

Solomon, S.: Stratospheric Ozone Depletion: A Review of Concepts and History, Rev. Geophys., 37, 275-316, 1999.

Solomon, S., Portmann, R. W., Garcia, R., Thomason, L. W., Poole, L. R., and McCormick, M. P.: The role of aerosol variations in anthropogenic ozone depletion at northern midlatitudes, J. Geophys. Res., 101, 6713-6727, 1996.

Solomon, S., Daniel, J. S., Neely III, R. R., Vernier, J.-P., Dutton, E. G., and Thomason, L. W.: The Persistently Variable "Background" Stratospheric Aerosol Layer and Global Climate Change, Science, 333, 866-870, 2011.

Sprenger, M. and Wernli, H.: A northern hemispheric climatology of cross-tropopause exchange for the ERA15 time period (19791993), J. Geophys. Res., 108, 8521 doi:10.1029/2002JD002636, 2003.

Sprenger, M., Croci Maspoli, M., and Wernli, H.: Tropopause folds and cross-tropopause exchange: A global investigation based upon ECMWF analyses for the time period March 2000 to February 2001, J. Geophys. Res., 108, 8518, doi:10.1029/2002JD002587, 2003.

Sprung, D. and Zahn, A.: Acetone in the upper troposphere/lowermost stratosphere measured by the CARIBIC passenger aircraft: Distribution, seasonal cycle, and variability, J. Geophys. Res., 115, D16301, doi:10.1029/2009JD012099, 2010.

Steinke, I., Möhler, O., Kiselev, A., Niemand, M., Saathoff, H., Schnaiter, M., Skrotzki, J., Hoose, C., and Leisner, T.: Ice nucleation properties of fine ash particles from the Eyjafjallajökull eruption in April 2010, Atmos. Chem. Phys., 11, 12945-12958, doi:10.5194/acp-11-12945-2011, 2011.
Stohl, A.: A 1-year Lagrangian"climatology" of airstreams in the Northern Hemisphere troposphere and lowermost stratosphere, J. Geophys. Res., 106, 7263-7279, 2001.

Stohl, A. and Trickl, T.: A textbook example of long-range transport: Simultaneous observation of ozone maxima of stratospheric and North American origin in the free troposphere over Europe, J. Geophys. Res., 104, 30445-30462, 1999.

Stohl, A., Bonasoni, P., Cristofanelli, P., Collins, W., Feichter, J., Frank, A., Forster, C., Gerasopoulos, E., Gäggeler, H., James, P., Kentarchos, T., Kromp-Kolb, H., Krüger, B., Land, C., Meloen, J., Papayannis, A., Priller, A., Seibert, P., Sprenger, M., Roelofs, G. J., Scheel, H. E., Schnabel, C., Siegmund, P., Tobler, L., Trickl, T., Wernli, H., Wirth, V., Zanis, P., and Zerefos, C.: Stratosphere-troposphere exchange - a review, and what we have learned from STACCATO, J. Geophys. Res., 108, 8516, doi:10.1029/2002JD002490, 2003.

Teitelbaum, H., Moustaoui, M., and Fromm, M.: Exploring polar stratospheric cloud and ozone minhole formation: The primary importance of synoptic-scale flow perturbations, J. Geophys. Res., 106, 28173-28188, 2001.

Tesche, M., Glantz, P., Johansson, C., Norman, M., Hiebsch, A., Ansmann, A., Althausen, D., Engelmann, R., and Seifert, P.: Volcanic ash over Scandinavia originating from the Grímsvötn eruptions in May 2011, J. Geophys. Res., 117, D09201, doi:10.1029/2011JD017090, 2012.

Thomason, L. W., Poole, L. R., and Deshler, T.: A global climatology of stratospheric aerosol surface area density deduced from stratospheric aerosol and gas experiment II measurements: 1984 1994, J. Geophys. Res., 102, 8967-8976, 1997.

Trepte, C. R. and Hitchman, M. H.: Tropical stratospheric circulation deduced from satellite aerosol data, Nature, 355, 626-628, 1992.

Trickl, T.: Upgraded 1.56- $\mu$ m lidar at IMK-IFU with $0.28 \mathrm{~J} /$ pulse, Appl. Opt., 49, 3732-3740, 2010.

Trickl, T., Cooper, O. C., Eisele, H., James, P., Mücke, R., and Stohl, A.: Intercontinental transport and its influence on the ozone concentrations over central Europe: Three case studies, J. Geophys Res., 108, 8530, doi:10.1029/2002JD002735, 2003.

Trickl, T., Feldmann, H., Kanter, H.-J., Scheel, H.-E., Sprenger, M., Stohl, A., and Wernli, H.: Forecasted deep stratospheric intrusions over Central Europe: case studies and climatologies, Atmos. Chem. Phys., 10, 499-524, doi:10.5194/acp-10-499-2010, 2010.

Trickl, T., Bärtsch-Ritter, N., Eisele, H., Furger, M., Mücke, R., Sprenger, M., and Stohl, A.: High-ozone layers in the middle and upper troposphere above Central Europe: potential import from the stratosphere along the subtropical jet stream, Atmos. Chem. Phys., 11, 9343-9366, doi:10.5194/acp-11-9343-2011, 2011.

Vernier, J.-P., Thomason, and Kar, J.: CALIPSO detection of an Asian tropopause aerosol layer, Geophys. Res. Lett., 38, L07804, doi:10.1029/2010GL046614, 2011a.

Vernier, J.-P., Thomason, L. W., Pommereau, J.-P., Bourassa, A., Pelon, J., Garnier, A., Hauchecorne, A., Blanot, L., Trepte, C., Degenstein, D., and Vargas, F.: Major influence of tropical volcanic eruptions on the stratospheric aerosol layer during the last decade, Geophys. Res. Lett., 38, L12807, doi:10.1029/2011GL047563, 2011b.

Vogelmann, H. and Trickl, T.: Wide-range sounding of freetropospheric water vapor with a differential-absorption lidar 
(DIAL) at a high-altitude station, Appl. Opt., 47, 2116-2132, 2008.

Vogelmann, H., Sussmann, R., Trickl, T., and Borsdorff, T.: Intercomparison of atmospheric water vapor soundings from the differential absorption lidar (DIAL) and the solar FTIR system on Mt. Zugspitze, Atmos. Meas. Tech., 4, 835-841, doi:10.5194/amt-4-835-2011, 2011.

Wernli, H. and Bourqui, M.: A Lagrangian "1-year climatology" of (deep) cross-tropopause exchange in the extratropical Northern Hemisphere, J. Geophys. Res., 107, 4021, doi:10.1029/2001JD000812, 2002.

Wirth, M., Fix, A., Ehret, G., Reichardt, J., Begie, R., Engelbart, D., Vömel, H., Calpini, B., Romanens, G., Apituley, A., Wilson, K. M., Vogelmann, H., and Trickl, T.: Intercomparison of Airborne Water Vapour DIAL Measurements with Ground Based Remote Sensing and Radiosondes within the Framework of LUAMI 2008, Contribution S07-P01-1 (3 pp.), in: Proceedings of the 8th International Symposium on Tropospheric Profiling (ISTP2009), Delft (The Netherlands), 19 to 23 October 2009, edited by: Apituley, A., Russchenberg, H. W. J., and Monna, W. A. A., RIVM, The Netherlands, http://cerberus.rivm.nl/ISTP/pages/index.htm, ISBN 978-90-6960-233-2, 2009.
Zanis, P., Trickl, T., Stohl, A., Wernli, H., Cooper, O., Zerefos, C., Gaeggeler, H., Schnabel, C., Tobler, L., Kubik, P. W., Priller, A., Scheel, H. E., Kanter, H. J., Cristofanelli, P., Forster, C., James, P., Gerasopoulos, E., Delcloo, A., Papayannis, A., and Claude, H.: Forecast, observation and modelling of a deep stratospheric intrusion event over Europe, Atmos. Chem. Phys., 3, 763-777, doi:10.5194/acp-3-763-2003, 2003. 